\title{
O QUE PENSAM AS LIDERANÇAS DE SÃO TOMÉ DAS LETRAS, MG, SOBRE AS QUESTÕES AMBIENTAIS DO MUNICÍPIO?
}

\section{WHAT DO SÃO TOMÉ DAS LETRAS LEADERS THINK ABOUT ENVIRONMENTALS QUESTIONS OF CITY?}

\author{
Renata de Melo Ferreira Lopes ${ }^{1}$, Valéria Lúcia de Oliveira Freitas², Paulina Maria Maia Barbosa ${ }^{3}$ \\ 'Graduação em Ciências Biológicas (2004), mestrado em Biologia Vegetal (2006) e doutorado em Ecologia, \\ Conservação e Manejo da Vida Silvestre (2012) pela Universidade Federal de Minas Gerais. \\ renatademeloferreira@yahoo.com.br \\ ${ }^{2}$ Graduação em Ciências Biológicas pela Universidade Federal de Minas Gerais (1988), doutora em Ecologia, \\ Conservação e Manejo da Vida Silvestre pela Universidade Federal de Minas Gerais (2012). Atualmente é \\ Pesquisadora do Instituto Cetec/Senai trabalhando com os temas anteriormente desenvolvidos.
} valeria.oliveira@fiemg.com.br

${ }^{3}$ Graduada em História Natural pela Universidade Federal de Minas Gerais (1975), mestrado em Ecologia e Recursos Naturais pela Universidade Federal de São Carlos (1982) e doutorado em Ecologia pela Universidade Federal do Rio de Janeiro (2000). Atualmente é professora associado da Universidade Federal de Minas Gerais. É coordenadora do ProLicenciatura da UFMG (ensino à distância do curso de Ciências Biológicas - Licenciatura). maia@icb.ufmg.br

http://dx.doi.org/10.5902/223613087077

\section{RESUMO}

O município de São Tomé das Letras está inserido na região sul do estado de Minas Gerais, na porção ocidental da serra da Mantiqueira, bacia do rio Grande, em área de transição entre o cerrado e a Floresta Atlântica. Possui 6.655 habitantes, altitude variando de $870 \mathrm{~m}$ a $1436 \mathrm{~m}$ e economia fundamentada em três atividades principais, geradoras de grandes alterações ambientais: o extrativismo mineral de quartzito, que ocupa até $70 \%$ da população ativa, a agropecuária e o turismo. O presente trabalho teve como objetivo o estudo da percepção ambiental de lideranças do município de São Tomé das Letras. Foram formuladas três hipóteses: 1) as lideranças possuem visão reducionista sobre o ambiente ao entendê-lo como o conjunto dos elementos naturais, excluindo o ser humano, 2) conhecem superficialmente os problemas ambientais de sua cidade e 3) suas razões conservacionistas são antropocêntricas. Foram realizadas entrevistas semi-estruturadas com 63 lideranças, sendo a amostragem estratificada por segmentos: social, político, econômico, educacional, ambiental, cultural, religioso, esportivo, associações comunitárias e órgãos públicos diversos. Os resultados indicaram que as lideranças conhecem os problemas ambientais da cidade e suas motivações conservacionistas são antropocêntricas e utilitaristas. A sustentabilidade socioambiental no município dependerá de acordos entre a classe trabalhadora, a classe que detém o poder econômico, entre os representantes legais da comunidade e os responsáveis diretos pela fiscalização e estruturação de suas principais atividades econômicas: a mineração de quartzito e o turismo.

Palavras-ChaveE: Percepção ambiental, mineração de quartzito, sustentabilidade socioambiental. 


\begin{abstract}
The municipality of São Tomé das Letras is located in the southern Minas Gerais State, in the western Mantiqueira Range, at the Rio Grande Basin, in a transition zone between the Cerrado and the Atlantic Forest. It has 6.655 habitants, altitude varying de $870 \mathrm{~m}$ a $1436 \mathrm{~m}$ and its economy is based on three main activities: the mining of quartzite (pedra são tomé), which employs $70 \%$ of the active population, agriculture and tourism. This work aims to study the environmental perception of leaders of the municipality. Three hypothesis were formed: 1 ) leaders has restrict vision about environment at understand it at a group of natural resources, excluding human people 2) know superficially the environmental problems of the city and 3) yours conservationist reasons are anthropocentric. Sixty three individuals were interviewed individually by semistructural interview (social, political, economical, educational, environmental, cultural, religious, sportive, communitarian associations and public institutions segments). The results indicated that the interviewed known about the environmental problems of the city, especially those of mining, and theirs reasons to conservation are anthropocentric and utilitarian. Socioambiental sustainability at the municipality will depends on accords among workers, class that has the economical powerful, legal representants of the community and the leaders of fiscalization and structuration of the mainly economical activities: quartzite mining and tourism.
\end{abstract}

Key-Words: environmental perception, quartzite minning, socioambiental sustentability.

\title{
INTRODUÇÃO
}

A implantação de planos de desenvolvimento econômico que contemplem as variáveis ambientais e sociais é um dos maiores desafios da atualidade, tendo em vista que são múltiplos e diversos os interesses e concepções acerca da temática ambiental. Tais concepções e necessidades ambientais ditam a forma de exploração dos recursos naturais pelo ser humano (MARIN et al., 2003; MORAN, 2010). De acordo com Bensusan et al. (2006), uma das concepções errôneas é a de que a tecnologia nos permite ter qualidade de vida, independente dos serviços ambientais advindos dos ecossistemas e da diversidade de espécies. Segundo Almeida e Bulhões (2006), muitas empresas de pequeno ou médio porte ainda demonstram preocupação com os custos decorrentes da preservação ambiental; essa concepção equivocada deve ceder lugar à conservação de recursos e ambientes, que garante o fornecimento de produtos e serviços de maior qualidade e, consequentemente, de maior vantagem competitiva no mercado, além de auxiliar na conservação da biodiversidade.

Da mesma forma que o ser humano modifica o ambiente físico, este influencia o seu comportamento (HEIMSTRA e MCFARLING, 1978). Os conceitos que os seres humanos têm sobre o meio ambiente, assim como aspectos associados à sua complexa evolução biológica e cultural, constituem, de acordo com Marin et al. (2003), os laços que unem pessoas e natureza, que devem ser resgatados com vistas à promoção da sustentabilidade dependente de inclusão social. Segundo os autores, a complexidade da natureza humana reflete a necessidade de entendimento da sua apreensão do mundo não somente pelos caminhos conceituais, como também pelo estudo das ligações estabelecidas pelo homem a outras formas de vida (biofilia) a aos componentes físicos do ambiente, a topofilia, termo primeiramente utilizado por Bachelard (BACHELARD, 1993).

Bergson, um dos pensadores que romperam com a era cartesiana e materialista da ciência, aponta para a importância da intuição como possibilitadora do contato com a realidade por meio da subjetividade, em oposição ao materialismo captado pela inteligência (BERGSON, 1999). Por 
sua vez, Merleau-Ponty, cuja obra está centrada na percepção, preocupa-se com o homem em seu meio natural, cultural e histórico. O pensamento merleau-pontyano procura superar o dualismo entre o sentir e o entender, defendendo a interação entre ambos, ressaltando a contribuição que a percepção dá para a concepção da verdade, encontrando na psicologia da forma, a ges/talt, a resposta para se libertar do intelectualismo. Para a psicologia da forma, o objeto é de imediato percebido na sua totalidade pela consciência, para posterior descoberta dos detalhes (MERLEAUPONTY, 2011; CARMO, 2011).

O conhecimento dos valores e significados que uma sociedade atribui ao ambiente com o qual interage é um pressuposto para uma sociedade sustentável. Segundo Tuan (1983), as aspirações e atitudes do ser humano em relação ao ambiente podem ser avaliadas com base nos estudos de seus valores, preferências e representações deste meio. Tais valores e significados constituem aquilo que chamamos de percepção ambiental, influenciada pelo contexto cultural em que os indivíduos se encontram (DEL RIO e OLIVEIRA, 1999; FERRARA, 1999). A partir do estudo dessas representações, pode-se dar início a reflexões quanto às reais necessidades e desejos dos indivíduos e às formas mais justas e limpas de apropriação do patrimônio natural e cultural de uma comunidade.

Um dos grandes pensadores da atualidade, Edgar Morin, autor de obras que discutem relações complexas entre ser humano, natureza e cultura, sustenta a idéia de que o pensamento disjunto e cartesiano que rege a ciência humana ocidental deve passar de simplificador e reducionista a multidimensional. A teoria moriniana discute que os elementos naturais e os grupos sociais devem ser compreendidos dentro de uma realidade socioambiental complexa (MORIN, 1991; 1997; 2008). Essa dimensão complexa da problemática socioambiental, que avança sobre o conceito de totalidade, sem reduzir às partes o universo físico, biológico e antropossocial, pode agregar novos e importantes elementos e reflexões para o campo da educação ambiental (DIAS, 2000).

O presente trabalho avaliou a percepção ambiental de indivíduos que ocupam cargos de liderança na cidade histórica de São Tomé das Letras, situada ao sul de Minas Gerais, que tem suas paisagens naturais alteradas por atividades antrópicas, especialmente pela extração de quartzito. Para tanto, foram formuladas três hipóteses de estudo: 1) as lideranças possuem visão reducionista do ambiente, ao entendê-lo como o conjunto dos elementos naturais, excluindo o ser humano; 2) conhecem superficialmente os problemas ambientais de sua comunidade e 3) suas razões conservacionistas são antropocêntricas.

\section{METODOLOGIA}

\section{Área de estudo}

O município de São Tomé das Letras está inserido na região sul do estado de Minas Gerais, na porção ocidental da serra da Mantiqueira, a $336 \mathrm{~km}$ de Belo Horizonte, em área de transição entre as florestas semidecíduas do sudeste e sul do país e o Cerrado do Brasil central (OLIVEIRA FILHO e FLUMINHAN-FILHO, 1999). Com uma população de 6.655 habitantes (IBGE, 2011), sua altitude varia de $870 \mathrm{~m}$ a $1436 \mathrm{~m}$ e alcança $1.290 \mathrm{~m}$ no núcleo urbano. A cidade estende-se por uma área de 398 km² e limita-se com os municípios de Três Corações, Luminárias, Conceição do Rio Verde, Baependi, Cruzília e São Bento Abade (DESCHAMPS et al., 2002). Apresenta pluviosidade média anual de 1.456 a $1.650 \mathrm{~mm}$ e clima tropical de altitude, com dias quentes e noites frias, 
temperatura anual média de $19^{\circ} \mathrm{C}$, mínima de $15^{\circ} \mathrm{C}$ e máxima de $26^{\circ} \mathrm{C}$ (INMET, 2011). Os principais rios que banham seu território são o rio do Peixe, rio Caí, ribeirão Vermelho, ribeirão do Forte e ribeirão Lavarejo. A maioria deles pertence à sub-bacia do rio Verde, que deságua no rio Grande, e apenas o Lavarejo e seus efluentes deságua diretamente na bacia do alto rio Grande (IGA, 2008).

A economia do município está fundamentada em três atividades principais: o extrativismo mineral, que ocupa até $70 \%$ da população ativa, a agropecuária e o turismo (DESCHAMPS et al., 2002). A cidade insere-se num complexo mineralógico de quartzito (MARQUES-NETO, 2008), conhecido como pedra são tomé, uma rocha metamórfica que contém de 70 a $95 \%$ de quartzo em sua estrutura (FERNANDES et al., 2002), usada no revestimento de pisos e paredes, sendo exportada para países da Europa e para o Japão desde a década de 1990 (Figs. 1, 2A e 2B). A cidade possui um patrimônio histórico datado do século XVIII, tombado pelo Instituto Estadual do Patrimônio Histórico e Artístico (IEPHA), com igrejas e casarios de quartzito, cujas pedras foram cuidadosamente cortadas e empilhadas uma a uma, sem qualquer tipo de argamassa, o que emprestou a ela o nome de "Cidade de Pedra" (D’AURIA, 2000) (Fig.2 C, E).

Por estar situada sobre a Serra de São Tomé (Fig.2 A), possui também um patrimônio natural singular (Fig.2 F), formado por várias nascentes, cachoeiras e grutas, que abrigam sítios arqueológicos representados por inscrições rupestres, alguns deles reconhecidos pelo Instituto do Patrimônio Histórico e Artístico Nacional (IPHAN) (Fig.2 C, D). Em 2009, foram localizadas 14 áreas com inscrições rupestres, sendo três na zona urbana, sete em áreas de mineração, duas na Área de Proteção Ambiental (APA) de São Tomé das Letras, uma na zona rural e uma no Pico do Peão, afastada de área de mineração; algumas delas com sinais de depredação (REZENDE et al., 2009). 


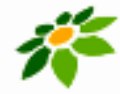

Monografias Ambientais

RENOANFSM

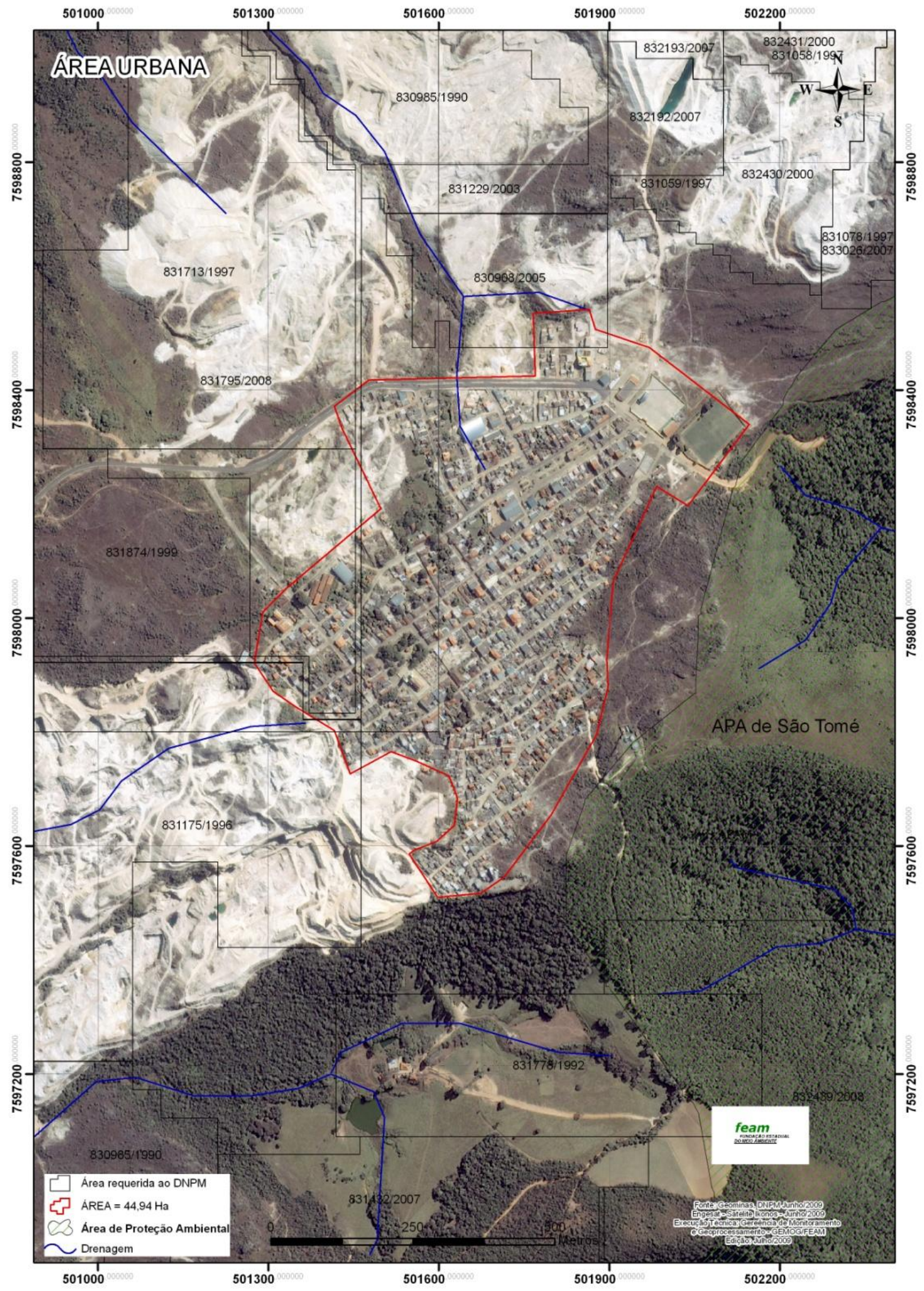

Figura 1. Vista aérea do município de São Tomé das Letras, MG. Fonte: Fundação Estadual do Meio Ambiente (2009). Área da zona urbana do município circundada em vermelho e cursos d'água destacados em azul. As áreas esbranquiçadas indicam locais de lavra ou pilhas de rejeito de quartzito. 

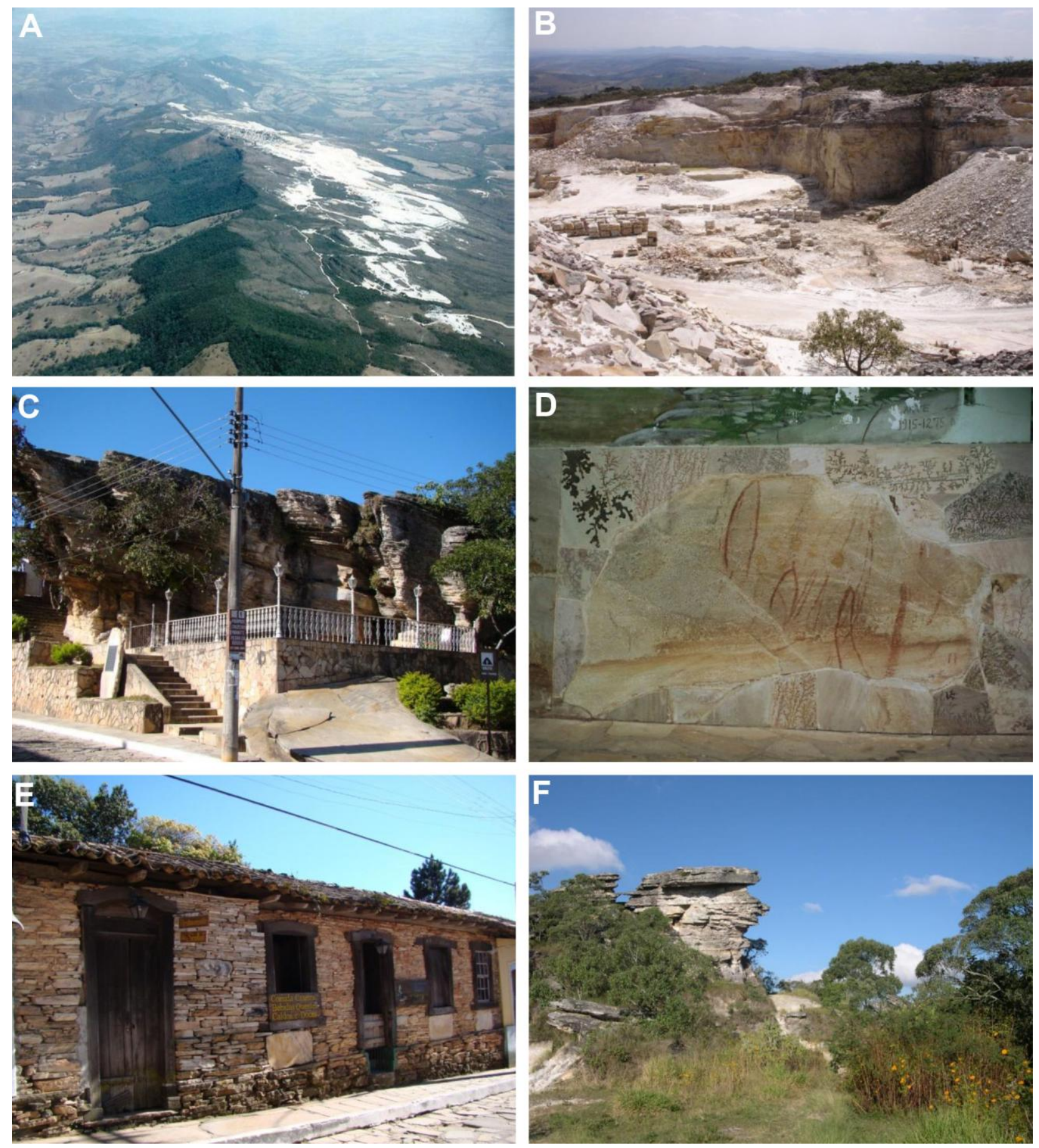

Figura 2. São Tomé das Letras, MG: A - Vista aérea da Serra de São Tomé (Fonte: AMIST, 2007). B - Lavra de quartzito, com detalhe de pilhas de rejeito de quartzito à direita e à esquerda. C - Gruta São Tomé, marco do início do povoamento da cidade. $D$ - Pinturas rupestres assentadas na fachada da pousada Mirante das Pedras, na Praça do Rosário. E - Construção em pedra do século XVIII. F - Pedra da Bruxa no Parque Municipal Antônio Rosa. Fonte (B a F): Laboratório de Restauração Ecológica CETEC/MG (2008). 
Consta que a extração das pedras teve início com a chegada dos colonizadores europeus no final do século XVIII, com a construção de igrejas e residências e pavimentação das ruas. A atividade foi retomada na segunda metade da década de 1940, com o surgimento da chamada "indústria da pedra", e intensificou-se na década de 1970, provavelmente pela incorporação de explosivos ao método de lavra (D’AURIA, 2000). Ainda hoje a mineração é realizada de forma rudimentar em muitas empresas, com processos de modernização ocorrendo em outras (CHIODI, 2003). Atualmente a mineração na região constitui o Aglomerado Produtivo Local São Tomé (APL São Tomé), uma vez que reúne empresas localizadas em um mesmo território, com especialização produtiva e vínculos entre si e entre instituições públicas e privadas (CHIODI-FILHO, 2006). Essa atividade gera intensa degradação ambiental na região, como alterações no relevo pelo acúmulo de rejeitos e empilhamento de estéreis, assoreamento de cursos d'água e perda de hábitat.

Em 1996, o Instituto Brasileiro de Turismo (EMBRATUR) concedeu à cidade o selo de potencial turístico, o que fez dela um integrante oficial do rol das principais cidades turísticas do sul de Minas Gerais, pertencendo também à Estrada Real, o maior projeto turístico já realizado no estado (PREFEITURA MUNICIPAL DE SÃO TOMÉ DAS LETRAS, 2011). A cidade está localizada em uma faixa correspondente ao domínio dos dobramentos pré-cambrianos do Sudeste brasileiro (MARQUES-NETO, 2008), e algumas de suas cavernas estão envoltas por lendas fantásticas, como sua suposta ligação à cidade de Machu Picchu, no Peru, através da Gruta do Carimbado I, com $33 \mathrm{~m}$ e a Gruta do Carimbado II, com 212m (TRAVASSOS, 2008). Segundo Drummond et al. (2005), é um dos municípios que contém cavernas e grutas quartzíticas com potencial para conservação de espécies de invertebrados, sendo recomendada a realização de inventários bioespeleológicos na sua área e a criação de unidades de conservação.

O misticismo chegou a São Tomé das Letras na década de 1930, com a instalação de um departamento da Sociedade Brasileira da Eubiose (SBE), antiga Sociedade Teosófica Brasileira. Esta Escola Iniciática tem como público-alvo "todos aqueles que desejarem pertencer à elite precursora da Nova Civilização, que fará seu surto nesta parte do Globo e para o qual foi a mesma criada" (DHÂRANÂ, 1957 apud D'AURIA, 2000). Para a SBE, São Tomé das Letras é uma das oito cidades especiais capazes de receber emanações de outras dimensões, mais propriamente, do Governo Oculto do Mundo (D'AURIA, 2000). A Sociedade recebe pessoas de todo o Brasil, em busca de cursos, palestras, massagens, ioga, meditações, culinária vegetariana etc.

A ambiência mística da cidade se consolidou na década de 70, com a chegada de integrantes do movimento hippie no município vizinho de Três Corações, através do evento Festival do Som, que atraiu "aventureiros" de todo o país; muitos deles fixaram residência em São Tomé das Letras e por ali ficaram. Já nessa época, a cidade atraia a atenção de ufólogos de vários estados brasileiros, que a consideravam um "portal de entrada no cosmos" (D'AURIA, 2000). Hoje, São Tomé das Letras é também conhecida como Cidade Mística, sendo o esoterismo um atrativo turístico para pessoas que buscam um encontro com o meio natural associado ao bem estar espiritual. Na cidade é possível nos depararmos com elementos ligados ao sobrenatural (bruxas, magos, ETs, duendes, naves espaciais) em diversos contextos, sejam presentes no artesanato, no vestuário, no modo de vida de moradores e turistas, ou nomeando e decorando estabelecimentos comerciais. 


\section{Coleta e análise de dados}

Para a coleta de dados junto à comunidade foi adotada a investigação quali-quantitativa (MINAYO e SANCHES, 1993). A primeira etapa consistiu na identificação e seleção de lideranças da cidade, que tivessem influência nas questões ambientais do município, com amostra estratificada por categorias: segmento social, político, econômico, educacional, ambiental, cultural, religioso, esportivo, associações comunitárias e órgãos públicos diversos. A segunda etapa consistiu na realização de entrevistas semi-estruturadas com as lideranças selecionadas. $O$ instrumento de coleta de dados foi um roteiro de entrevistas contendo perguntas abertas dirigidas oralmente aos entrevistados (Anexo 1). As questões permitiram levantar o perfil social dos participantes, estudar a percepção dos mesmos em relação ao patrimônio natural e construído da cidade de São Tomé das Letras, assim como em relação à identificação, compreensão e consciência crítica das alterações ambientais locais ocorridas ao longo do tempo. Os indivíduos foram entrevistados individualmente, sendo as falas dos participantes gravadas em gravador digital e posteriormente transcritas. As entrevistas foram concedidas após assinatura, pelos participantes, do Termo de Consentimento Livre e Esclarecido, de acordo com as normas do Comitê de Ética e Pesquisa da Universidade Federal de Minas Gerais (CAAE - 0377.0.203.000-10). Algumas falas foram utilizadas para ilustrar o texto, sem grandes alterações de sua estrutura gramatical.

Os dados quantitativos foram categorizados no programa Microsoft Office Excel 2007, sendo convertidos em valores de porcentagem. As percepções das lideranças foram contrastadas com dados da literatura e de órgão gestores. Para categorizar as respostas dos entrevistados quanto à definição de meio ambiente, foi utilizada a classificação de Sauvé (1996), que propõe: ambiente como Natureza, para ser apreciado, respeitado e preservado; ambiente como Recurso, para ser manejado; ambiente como Problema, para ser solucionado; ambiente como Lugar para se Viver, para ser conhecido e cuidado; ambiente como Biosfera, onde vivemos todos juntos, em longo prazo, e ambiente como Projeto Comunitário, pelo qual somos responsáveis.

\section{RESULTADOS E DISCUSSÃO}

Foram entrevistadas 63 lideranças da cidade (Tab. 1), 70\% delas do sexo masculino (Tab.2). Essa diferença na representatividade entre os sexos possui raízes históricas provenientes de uma sociedade patriarcal, onde às mulheres coube o trabalho doméstico desprovido de participação política, o que ainda gera reflexos atuais na organização dos gêneros em nossa sociedade (LOPES, 2006).

A idade média dos entrevistados foi de 45 anos, com número médio de filhos de 2,6. A maioria dos participantes da pesquisa é casada, mora na zona urbana e se declarou católica (Tab. 2). Dezoito pessoas declararam não possuir religião. Apesar dessa pesquisa evidenciar uma maioria católica, São Tomé das Letras agrega muitas pessoas não católicas, cuja espiritualidade não está diretamente dependente de uma instituição religiosa; essas pessoas se dizem espiritualistas, espiritualizadas, ligadas à natureza, esotéricas, místicas. 
Tabela 1. Ramos de atuação das lideranças entrevistadas. $\mathrm{N}=$ número de indivíduos. Código = código utilizado para preservar a identidade das lideranças nas citações de suas falas.

\begin{tabular}{|c|c|c|}
\hline Lideranças representadas & $\mathbf{N}$ & Código \\
\hline Agricultura & 4 & AGRIC (1 a 4) \\
\hline Associações e ONG ${ }^{1}$ & 7 & ASSOC ( 1 a 7$)$ \\
\hline Comunicação & 2 & COMUNIC (1 a 2$)$ \\
\hline Líder comunitário & 4 & COMUNID (1 a 4 ) \\
\hline Educação & 7 & $\operatorname{EDU}(1 \mathrm{a} 7)$ \\
\hline Extrator de pedra & 5 & EXTRAT (1 a 5) \\
\hline Líder religioso & 6 & RELIG (1 a 6$)$ \\
\hline Minerador & 5 & MINER (1 a 5) \\
\hline Empresas de capital misto e Órgão Público ${ }^{2}$ & 6 & CM/O.PUB (1 a 6$)$ \\
\hline Poder público ${ }^{3}$ & 9 & POD.PÚB (1 a 11) \\
\hline Turismo/Comércio & 8 & TUR/COM (1 a 8) \\
\hline
\end{tabular}

1 - Associação das Empresas Mineradoras, Beneficiadoras e de Comércio de Quartzitos da Região de São Tomé das Letras (AMIST); Associação de Guias e Profissionais do Turismo de São Tomé das Letras (AGIPROTUR); Associação dos Artesãos de São Tomé das Letras; Associação Esportiva de São Tomé das Letras; Associação dos Pais e Amigos dos Excepcionais (APAE); Sociedade Brasileira da Eubiose; ONG Circo Criação de Criança.

2 - Companhia Energética de Minas Gerais (CEMIG); Companhia de Saneamento de Minas Gerais (COPASA); Empresa de Assistência Técnica e Extensão Rural do estado de Minas Gerais (EMATER); Sistema Único de Saúde (SUS); Polícia Militar.

3 - Prefeitura: Poder Executivo, Departamento Administrativo, Departamento de Meio Ambiente; Conselho Municipal de Desenvolvimento Ambiental (CODEMA), Câmara dos Vereadores.

Das 63 lideranças entrevistadas, quase $25 \%$ nasceram e viveram no estado de São Paulo e em outras cidades de Minas Gerais (Tab.2) e 17 pessoas não mencionaram a naturalidade, uma questão não contemplada no roteiro de entrevistas. A média de moradia no município é de 22 anos. No início da década de 80, o governo do Estado doava lotes na região, sob a condição que o imóvel fosse construído no prazo de um ano, o que permitiu a fixação de pessoas oriundas de outras localidades em São Tomé das Letras (D'AURIA, 2000).

Tabela 2. Perfil social de lideranças de São Tomé das Letras, MG.

\begin{tabular}{|c|c|c|c|c|c|c|c|c|c|c|c|}
\hline $\begin{array}{l}\text { Estado } \\
\text { Civil }\end{array}$ & $\mathbf{N}$ & $\%$ & Religião & $\mathbf{N}$ & $\%$ & Residência & $\mathbf{N}$ & $\%$ & Naturalidade & $\mathbf{N}$ & $\%$ \\
\hline & 4 & & & 3 & & & 4 & & São Tomé das & 2 & \\
\hline \multirow[t]{2}{*}{ Casado } & 1 & 65,1 & Católico & 3 & 52,4 & Zona urbana & 1 & 65,1 & Letras & 5 & 39,7 \\
\hline & 1 & & Sem & 1 & & & 1 & & & 1 & \\
\hline Solteiro & $\begin{array}{l}0 \\
1\end{array}$ & 15,9 & religião & $\begin{array}{l}8 \\
1\end{array}$ & 28,6 & $\begin{array}{l}\text { Zona rural } \\
\text { Outras }\end{array}$ & 7 & 27,0 & São Paulo & 5 & 23,8 \\
\hline \multirow[t]{2}{*}{ Outros } & 2 & 19,0 & Outras & 2 & 19,0 & cidades & 5 & 7,9 & Minas Gerais & 6 & 9,5 \\
\hline & $\begin{array}{l}6 \\
3\end{array}$ & 100, & TOTAL & $\begin{array}{l}6 \\
3\end{array}$ & $\begin{array}{c}100, \\
0\end{array}$ & TOTAL & $\begin{array}{l}6 \\
3\end{array}$ & $\begin{array}{c}100, \\
0\end{array}$ & Sem resnosta & $\begin{array}{l}1 \\
7\end{array}$ & 270 \\
\hline TOTAL & & & & & & & & & TOTAL & $\begin{array}{l}6 \\
3\end{array}$ & $\begin{array}{c}100, \\
0\end{array}$ \\
\hline
\end{tabular}

$38 \%$ dos entrevistados concluíram o terceiro grau (Tab. 3). $25 \%$ dos entrevistados concluiu apenas o ensino fundamental, sendo essas pessoas as mais idosas, cujos estudos ficaram 
comprometidos por falta de fornecimento de todas as séries escolares na época em que eram jovens, segundo os próprios participantes.

Tabela 3. Escolaridade das lideranças de São Tomé das Letras, MG.

\begin{tabular}{lcc}
\hline Escolaridade & $\mathbf{N}$ & \% \\
\hline Ensino fundamental completo & 16 & 25,4 \\
Ensino médio completo & 4 & 6,3 \\
Segundo grau completo & 15 & 23,8 \\
Terceiro grau completo & 20 & 31,7 \\
Terceiro grau incompleto & 4 & 6,3 \\
Pós-graduação & 4 & 6,3 \\
\hline
\end{tabular}

Quando perguntados sobre as "coisas boas da cidade de São Tomé das Letras e seus arredores", as palavras-chave que mais apareceram nas falas dos entrevistados foram pessoas (46\% dos entrevistados), natureza (44\%), cachoeiras (29\%), paisagens/vista da cidade (22\%), clima (21\%) e turismo (18\%) (Tab. 4). Nota-se a importância do elemento humano e dos elementos naturais nesta questão. Os entrevistados, em vários momentos, referiram-se aos moradores de São Tomé das Letras, especialmente aos nativos, como um povo trabalhador, sábio, tranquilo:

TUR/COM 7 - Lindo demais isso aqui. (...), quando eu vim pra cá, São Tomé das Letras não era um lugar totalmente sem estrutura, mas era um lugar que valorizava muito a pessoa. Acho que na cidade grande, certos valores se perderam. São Tomé das Letras não, as pessoas não estavam muito interessadas em saber qual é a sua formação, qual era o carro... era assim: "Quem é você? Você veio aqui por quê? O que te levou a fazer essa mudança?" (...). Tem o lado de qualidade de vida, tem o aspecto de serenidade que a própria montanha propicia, de interiorização, de autoconhecimento.

Tabela 4. Do que as lideranças de São Tomé das Letras, MG, mais gostam no município.

\begin{tabular}{lcc|lcc}
\hline Palavras-chave & $\mathbf{N}$ & $\mathbf{\%}$ & Palavras-chave & $\mathbf{N}$ & $\mathbf{\%}$ \\
\hline Pessoas & 29 & 46,0 & Centro histórico & 3 & 4,8 \\
Natureza & 28 & 44,4 & Atividades religiosas & 2 & 3,2 \\
Cachoeiras & 18 & 28,6 & Lendas & 2 & 3,2 \\
Paisagem/vista da cidade & 14 & 22,2 & Qualidade de vida & 2 & 3,2 \\
Clima & 13 & 20,6 & Ar puro & 1 & 1,6 \\
Turismo & 11 & 17,5 & Ausência de mendigo & 1 & 1,6 \\
Tranquilidade/segurança & 7 & 11,1 & Charme da cidade & 1 & 1,6 \\
Mineração & 6 & 9,5 & Cidade no alto da montanha & 1 & 1,6 \\
Montanhas/relevo & 6 & 9,5 & Diversidade cultural & 1 & 1,6 \\
Vegetação & 6 & 9,5 & Igreja do Rosário & 1 & 1,6 \\
Grutas & 5 & 7,9 & Noite da cidade & 1 & 1,6 \\
Misticismo & 5 & 7,9 & Pirâmide & 1 & 1,6 \\
Zona rural & 4 & 6,3 & Pôr do sol & 1 & 1,6 \\
Parque Municipal Antônio Rosa & 3 & 4,8 & Vento & 1 & 1,6 \\
\hline
\end{tabular}


A natureza foi citada essencialmente pelo sentimento de beleza que evoca nos entrevistados, sendo, para eles, um elemento que em muito define o município. Natureza, Paisagens/vista da cidade e Montanhas/relevo estão presentes em quase $80 \%$ dos relatos. Cachoeiras, bastante comuns na cidade, uma vez que o município está cravado sobre a Serra de São Tomé, foram ressaltadas por 18 participantes como importantes centros de lazer, de encontros em família e elemento de atração essencial para o turismo. Para Farias (2008), o ambiente natural é procurado pelos trabalhadores urbanos em seu tempo livre, também pela oportunidade que ele oferece de contemplação do belo, segurança e tranquilidade, haja vista a preocupação constante das pessoas para responderem às exigências de produtividade da sociedade contemporânea. No entanto, pouquíssimas referências a áreas naturais específicas foram apontadas pelos entrevistados, como o Parque Municipal Antônio Rosa, uma área protegida no limite sudeste da área urbana de São Tomé das Letras, onde estão vários pontos turísticos como o Cruzeiro, a Pirâmide, a Pedra da Bruxa, o Mirante e as caixas d'água que lembram discos voadores. Pontos importantes, como a Área de Proteção Ambiental de São Tomé das Letras Unidade de Conservação que abriga várias nascentes e apresenta sua área coincidindo com áreas de maior disponibilidade de matéria prima minerária na região (DNPM, 2009), não foram citados.

Já o clima foi lembrado por manter a cidade sempre fresca e agradável durante a maior parte do ano, e o turismo como importante fonte de renda para a região, assim como de experiências e ideias novas advindas do contato dos moradores com pessoas não residentes:

POD.PUB 11 - É bonito [o turismo na cidade], me sinto bem e isso atrai as pessoas pra cá, constitui uma convivência com pessoas de diferentes lugares, diferentes cabeças. Eu gosto disso, dessa mistura de ideias de pessoas que vem de vários lugares, vários centros que se encontram aqui.

Apesar da mineração de quartzito empregar cerca de 70\% da população local (DESCHAMPS et al., 2002), apenas seis entrevistados fizeram menção a essa atividade como um ponto positivo do município (Tab.4), pela oportunidade de trabalho que ela gera. Fica evidente que as autoridades de São Tomé das Letras não fazem uma associação direta entre a atividade extrativa de quartzito e "as coisas boas da cidade", indicando uma possível incompatibilidade, para os entrevistados, entre a manutenção das coisas positivas da cidade, citadas por eles (natureza, cachoeiras, paisagens/vista da cidade) e a mineração.

Quando arguidos sobre "coisas que mudariam na cidade e seus arredores", as respostas foram bem variadas, sendo os problemas diretamente relacionados à mineração de quartzito, ressaltados por quase $80 \%$ dos entrevistados (Tab. 5). Dentre eles receberam destaque a degradação ambiental causada pela atividade extrativa; o mau aproveitamento do quartzito extraído, que resulta em grandes pilhas de rejeito de pedra abandonadas nas áreas mineradas, gerando poluição visual acentuada; a extração da pedra dentro do perímetro urbano; a falta de compensação ambiental e retorno social por parte das mineradoras, e a praticamente inexistência de projetos de restauração ecológica na região. Essa pergunta de certa forma complementa a questão sobre as "coisas boas da cidade de São Tomé das Letras e seus arredores": a atividade extrativa deixa de ser citada lá para ser lembrada aqui, como uma "coisa a ser mudada na cidade".

A má estruturação do turismo foi lembrada por $24 \%$ dos entrevistados, e ações políticas ineficientes e desinteressadas dos problemas reais da cidade, por 22\% (Tab. 5). Outro aspecto negativo, citado por quase $1 / 4$ das lideranças, foi a arquitetura urbana descaracterizada, vista como desvalorização do patrimônio histórico-cultural da cidade. Importante destacar que apenas três pessoas citaram o patrimônio histórico de São Tomé das Letras como uma "coisa boa da cidade". É possível perceber que a expansão da área urbana do município está se dando de forma 
desordenada, sem planejamento e sem assegurar um estilo arquitetônico que preserve as construções remanescentes:

RELIG 1 - O patrimônio histórico de São Tomé das Letras, eu reconstruiria tudo. Sumiria aqueles fios da CEMIG na Praça do Rosário. Sabe aquelas construções de dois andares, sei lá quantos andares da Praça do Rosário? Arrancava aquilo de lá tudo, e cortava aqueles fiozinhos da CEMIG todos.

EDU 1 - Daí a degradação, porque São Tomé das Letras tem esse problema. A escola José Cristiano Alves... ela é centenária, ela tem 107 anos e quem chega e olha pela primeira vez, pensa que a escola foi construída ontem. Ela não tem um acervo histórico. Para não dizer que ela não tem um acervo histórico ela tem um sino. Um sino! Lá no canto da secretaria.

A má qualidade da educação escolar, a falta de opções de atividades culturais e a pouca atenção das autoridades competentes em relação ao saneamento (limpeza urbana e coleta de lixo, lançamento de esgoto em corpos d'água e presença de muitos cães nas ruas) foram citados por $16 \%$ dos participantes (Tab. 5). Segundo a FEAM (2009), o Ribeirão Caninana, na entrada do município, recebe esgoto doméstico e, em sua área de influência, são desenvolvidas atividades de lavra e beneficiamento de quartzito. Já a presença de inúmeros cães nas ruas, e mesmo dentro de estabelecimentos comerciais, pode ser percebida por qualquer indivíduo que transite pelas ruas da cidade. Cinco entrevistados mostraram-se insatisfeitos com a má administração do Parque Municipal Antônio Rosa. A proximidade do Parque à sede do município e a inexistência de barreira física que defina os limites do mesmo o torna alvo de ocupações irregulares.

Tabela 5. O que as lideranças de São Tomé das Letras, MG, mudariam no município e arredores. Continua...

\begin{tabular}{lcc}
\hline Palavras-chave & $\mathbf{N}$ & $\%$ \\
\hline Degradação ambiental da mineração/desperdício de pedra e poluição visual/extração & 5079, \\
no perímetro urbano/falta de compensação e restauração & 3 \\
& 15, & 23, \\
& 8 \\
Turismo mal estruturado, mal planejado & 23, \\
Arquitetura urbana descaracterizada/desvalorização do patrimônio histórico e da & 15 \\
cultura local & 82, \\
& 14 \\
Políticos incompetentes & 2 \\
& 10, \\
Educação escolar fraca e descontextualizada & 9 \\
& 10 & 15, \\
Falta de opções de eventos culturais & 9 \\
Limpeza urbana e coleta de lixo ineficientes na cidade/esgoto em corpos d água/ & 10 \\
cães abandonados nas ruas & 15, \\
Uso de drogas no município (álcool, maconha, cocaína, crack) & 9 \\
Saúde precária, centralizada & 7,9 \\
Falta de investimento na proteção ao ambiente (queimadas, falta de arborização & 5 & 7,9 \\
urbana, Parque Municipal descuidado e invadido) & 5 & 7,9 \\
Falta de participação política do povo & 4
\end{tabular}




\begin{tabular}{lcc}
\hline Palavras-chave & $\mathbf{N}$ & $\mathbf{\%}$ \\
\hline Má profissionalização de prestadores de serviços & 2 & 3,2 \\
Imagem da cidade associada ao uso livre de drogas & 2 & 3,2 \\
Estradas sem asfalto & 2 & 3,2 \\
Abuso de autoridade policial & 2 & 3,2 \\
Tráfico de influência & 1 & 1,6 \\
Poucas opções de comércio & 1 & 1,6 \\
Falta de incentivo ao esporte & 1 & 1,6 \\
Falta de apoio financeiro do governo estadual & 1 & 1,6 \\
Falta de espiritualidade nas pessoas & 1 & 1,6 \\
Condições inadequadas de trabalho nas pedreiras & 1 & 1,6 \\
Tráfego de caminhões pelas ruas da cidade & 1 & 1,6 \\
\hline
\end{tabular}

Os participantes da pesquisa associaram o meio ambiente, primeiramente, a um Lugar para se Viver (Tab. 6):

RELIG 4 - o que é meio ambiente... O meio ambiente é o lugar onde a gente vive. É toda a estrutura que a gente tem, do nosso habitat, sejam as árvores, as pastagens, as formações rochosas, enfim, tudo que tá à nossa volta.

COMUNID 4 - É exatamente todo o meio que nós vivemos. (...) todo local físico que nós passamos é o meio ambiente. Não só as florestas, mas a cidade, nosso quintal, nossa rua, tudo ao seu redor.

Meio ambiente como Biosfera foi lembrado por $20 \%$ dos entrevistados (Tab.6):

TUR/COM 4 - ... e quando eu falo meio ambiente, pra mim o que vem na minha imagem é o planeta, é o planeta Terra, as coisas que agora estão desequilibradas, e é um planeta que se auto regula, eu tenho essa visão, como eles chamam... de Gaia, né, que é um ser vivo. (...). Eu vejo o meio ambiente não como uma coisa, uma cachoeira, eu imagino já a Terra, o planeta inteiro, como sendo o local onde a gente vive.

TUR/COM 8 - Acho que meio ambiente é a relação dos seres vivos desse planeta com outros seres vivos. É a integração entre os seres vivos, né? Eu acho que o ser humano se afastou um pouco dessa relação, se considerando um ser divino, antes de se considerar um ser vivo, como qualquer micro organismo existente, né? Então, eu acho que o ser humano se afastou dessa relação real de vida, pra ficar fluindo na espiritualidade, na divindade, puramente humana, não cósmica. Porque é o que eu falei, pra mim o tucano é muito mais cósmico do que qualquer santo que você vai me mostrar, preso num papel ou num quadrinho das pessoas, ou em qualquer altar, entendeu? Então o meio ambiente pra mim é isso, a relação entre os seres vivos.

Meio ambiente como Problema e como Recurso foi definido, ambos, por $14 \%$ dos entrevistados (Tab.6). Quando Problema foi visto como o lugar onde é preciso reflorestar, despoluir, estruturar etc.:

TUR/COM 6 - Ah, o meio ambiente é você proteger a natureza, os rios, as nascentes. $O$ meio ambiente é você reflorestar, é não jogar lixo na cidade... Meio ambiente é tudo isso, né? 
Já meio ambiente como Recurso (Tab.6):

MINER 4 - Eu acho que, antes de mais nada, o meio ambiente é aquilo que a gente extrai, devíamos extrair melhor do lugar onde a gente vive. (...) basicamente eu sei que é um conceito muito difícil, muito difuso, mas pra mim, eu acho que nós teríamos um melhor meio ambiente, tanto quanto nós pudéssemos trabalhar melhor isso.

Meio ambiente foi definido como Natureza e Projeto Comunitário, ambos, por $10 \%$ dos entrevistados (Tab.6). Como Projeto Comunitário:

ASSOC 3 - Eu acho que meio ambiente é tudo, não só o meio, mas é tudo, é aquilo que a gente vive, onde a gente está inserido, o local físico, o local aonde você tem a troca de energia com as pessoas, onde você mora, onde você ganha seu dinheiro. Não é só questão da natureza. A natureza é o primordial, principal. Mas o ambiente é tudo que está a sua volta, até mesmo com as pessoas. É o ambiente em que você vive, as pessoas que você se relaciona, que você encontra, que podem te ajudar, ou também que você pode ajudar em alguma coisa. É a convivência.

Tabela 6. Conceituação de "meio ambiente" segundo lideranças de São Tomé das Letras, MG.

\begin{tabular}{lcc}
\hline O que é meio ambiente para você? & $\mathbf{N}$ & $\mathbf{\%}$ \\
\hline Lugar para se viver & 21 & 33,3 \\
Biosfera, onde vivemos todos juntos, em longo prazo & 13 & 20,6 \\
Problemas que devemos solucionar & 9 & 14,3 \\
Recursos que devemos manejar & 9 & 14,3 \\
Natureza que devemos apreciar, cuidar e respeitar & 6 & 9,5 \\
Projeto Comunitário pelo qual somos responsáveis & 5 & 7,9 \\
\hline
\end{tabular}

Nota-se uma tendência à concepção utilitarista de meio ambiente, quando este é visto como Lugar para se Viver pela maioria, ou como Recursos que devem ser manejados. De acordo com as diferentes definições de meio ambiente, Sauvé et al. (2000) indicaram estratégias pedagógicas que podem ser utilizadas em práticas de educação ambiental. Se o ambiente é classificado como Natureza, são sugeridas atividades ao ar livre, como interpretação de trilhas, contemplação de paisagens naturais e desenvolvimento do sentimento de pertencimento ao meio natural. No caso das lideranças de São Tomé das Letras seria importante seu acesso destas a documentos e registros históricos de áreas naturais e construídas da cidade e a mapas que localizassem áreas importantes do município, como o Parque Municipal Antônio Rosa, a Área de Proteção Ambiental de São Tomé das Letras, as cachoeiras, grutas e suas inscrições rupestres, e mesmo o centro histórico da cidade. Algumas iniciativas nesse sentido já foram tomadas, junto aos professores do município, por uma historiadora residente na cidade, e tiveram ótima receptividade.

A pedra são tomé foi citada como um dos elementos que mais simbolizam o município, seguida de apóstolo Tomé, cachoeiras, casinha de pedra (artesanato típico da região), pôr do sol e natureza (Tab. 7), embora quase $10 \%$ dos entrevistados tenha tido dificuldade em identificar algo que pudesse representar a cidade. Muitos outros elementos naturais e históricos foram citados, como a árvore de candeia (Eremanthus spp.), a serra de São Tomé, as Igrejas da Matriz e do Rosário e as pinturas rupestres. Nota-se que os símbolos escolhidos foram bem diversos, sendo a 
pedra são tomé o mais representativo deles, mas a atividade extrativa em si, como símbolo de cidade, foi mencionada apenas por um entrevistado, assim como "Gruta" e "Estrada Real". A Estrada Real constitui um campo promissor para a conservação de geoambientes e para o geoturismo em São Tomé das Letras, uma vez que trechos dela encontram-se sobre a Gruta do Labirinto (MG-1681) com 266m de extensão e a Gruta do Sobradinho (MG-1682) com 150m de extensão, ambas em quartzito (TRAVASSOS, 2008).

Tabela 7. Símbolos que bem representariam a cidade de São Tomé das Letras, MG, segundo suas lideranças.

\begin{tabular}{lcclcc}
\hline Símbolos & $\mathbf{N}$ & $\mathbf{\%}$ & Símbolos & $\mathbf{N}$ & $\mathbf{\%}$ \\
\hline Pedra são Tomé & 8 & 12,7 & Árvore & 1 & 1,6 \\
Não sei & 6 & 9,5 & Chico Taquara & 1 & 1,6 \\
Apóstolo Tomé & 4 & 6,3 & Coração & 1 & 1,6 \\
Cachoeira & 3 & 4,8 & Esportes de aventura & 1 & 1,6 \\
Casinha de pedra & 3 & 4,8 & Estrada Real & 1 & 1,6 \\
Pôr do sol & 3 & 4,8 & Folha de maconha & 1 & 1,6 \\
Natureza & 3 & 4,8 & Mineração & 1 & 1,6 \\
Árvore Candeia & 2 & 3,2 & Montanha & 1 & 1,6 \\
Estrela & 2 & 3,2 & Natureza e os três poderes & 1 & 1,6 \\
Igreja Matriz & 2 & 3,2 & Pedra do Guardião & 1 & 1,6 \\
Igreja Rosário & 2 & 3,2 & Disco voador & 1 & 1,6 \\
Liberdade & 2 & 3,2 & Pirâmide de pedra & 1 & 1,6 \\
Pomba branca & 2 & 3,2 & Pirâmide invertida & 1 & 1,6 \\
Turismo & 2 & 3,2 & Serra de São Tomé & 1 & 1,6 \\
Pinturas rupestres & 2 & 3,2 & Superação & 1 & 1,6 \\
Misticismo & 1 & 1,6 & Gruta & 1 & 1,6 \\
Anjo & 1 & 1,6 & Vida rural & 1 & 1,6 \\
\hline
\end{tabular}

Em relação às fontes de informações sobre questões ambientais utilizadas pelas lideranças do município, quase $50 \%$ dos participantes declararam utilizar mais de uma fonte, sendo incluídas na categoria "Diversos" as respostas que apresentaram três ou mais fontes (internet, televisão e pessoas, por exemplo) (Tab. 8):

TUR/COM 4 - Através de leitura, principalmente, livro, internet, na mídia normal, televisão e tudo. Agora, na cidade não, através de vivência mesmo, de ir nos locais e conhecer o que está acontecendo, o que não está acontecendo. (...) como trabalho muito com turista, num passeio que faço, numa caminhada, às vezes recebo informações deles. Uma troca, na verdade.

O acesso facilitado à internet, em tempos atuais, a torna um objeto de uso geral e diário, sendo refletido nessa pesquisa como principal ferramenta para obtenção de informações ambientais (incluindo-se especialmente na categoria "Diversos"). Temas relativos à problemática ambiental do município atualmente são discutidos em blogs e na rede social Facebook, ferramentas de comunicação com potencial relevante para gerar informações e debate de ideias, que podem resultar em ativa participação política, o que as tornam dignas de atenção por parte das autoridades da cidade. Os órgãos públicos da cidade e as conversas informais entre os 
moradores poderiam também ser de grande valia para levar o conhecimento da realidade ambiental para a comunidade. No entanto, essas fontes foram pouco citadas (Tab.8).

Dos entrevistados, $16 \%$ afirmaram não se informar sobre o tema (Tab.8), estando o segmento religioso e lideranças com baixa escolaridade, bem representados nessa categoria. Entretanto, essas mesmas lideranças não demonstraram desconhecimento das questões ambientais importantes da cidade, suas falas não destoaram das demais. A problemática ambiental de São Tomé das Letras está tão presente na vida de seus moradores que ela, por si só, cria seus modos de inserção e exclusão, de modo a envolver todos que ali habitam. Entretanto, é de se esperar que uma fonte confiável de informações seja utilizada pelas autoridades do município para a discussão e reflexão sobre as soluções que os cidadãos são-tomeenses realmente desejam para a cidade.

Tabela 8. Fontes de informação sobre temas ambientais das lideranças de São Tomé das Letras, MG.

\begin{tabular}{lcc}
\hline Você se informa sobre o meio ambiente? Como? & $\mathbf{N}$ & $\mathbf{\%}$ \\
\hline Sim. Diversos & 31 & 49,2 \\
Sim. Internet & 9 & 14,3 \\
Sim. Pessoas & 6 & 9,5 \\
Sim. Televisão & 6 & 9,5 \\
Não me informo & 10 & 15,9 \\
\hline
\end{tabular}

Em relação à época ideal para o início do aprendizado sobre questões ambientais, os entrevistados se dividem em dois grupos. Metade deles acredita que a abordagem de temas ambientais deveria ser uma prática constante na vida das pessoas, desde o seu nascimento, ou quando já apresentassem maturidade para apreender conceitos, e não algo a ser discutido apenas no ambiente escolar (Tab. 9):

TUR/COM 6 - A partir dos oito anos de idade eu acho que a criança já tem que ter uma consciência ecológica. Meus filhos já estão com oito anos e já estão com consciência ecológica. Eu já ensino tudo. Que nem eu, eu vou pegar uma água e exagero, minha filha já fica brava comigo. Então ela já tem uma consciência ecológica, isso é muito bom!

Praticamente a outra metade dos entrevistados, entretanto, fez uma associação direta entre a aprendizagem de conceitos ambientais pelas crianças e a escola, ou seja, a educação formal (Tab.9). Porém, dentro do contexto familiar e social, temas importantes ligados à questão ambiental podem e devem ser introduzidos no cotidiano infantil desde os primeiros anos de vida, sem estarem, necessariamente, ligados às atividades escolares (PERUZZO, 2002). Gohn (2006) acredita que a educação não formal (aprendida intencionalmente em espaços e ações coletivas cotidianas), assim como a informal (aprendida não intencionalmente durante o processo de socialização), educam o ser humano para a civilidade, sendo fundamentais para sua formação política, para o desenvolvimento de sua consciência, visões de mundo e solidariedade. 
Tabela 9. Melhor idade para introdução de conceitos ambientais, segundo as lideranças de São Tomé das Letras, MG.

\begin{tabular}{lcc}
\hline Qual a melhor idade para começar a aprender sobre o meio ambiente? & N & \% \\
\hline Desde o nascimento / quando se adquire consciência & 33 & 52,4 \\
Na pré-escola / A partir dos 6 anos & 29 & 46,0 \\
Todas as idades & 1 & 1,6 \\
\hline
\end{tabular}

As respostas à questão "Você acha que causa algum prejuízo ao meio ambiente? Por quê?" permitiram averiguar a consciência crítica dos participantes em relação ao reconhecimento do impacto de suas atividades sobre o meio natural. Mais de $20 \%$ deles acredita não causar nenhum dano ambiental (Tab. 10), seja porque separam o lixo não orgânico do orgânico, utilizando o segundo como adubo, ou porque não fumam, não caçam ou não jogam lixo na rua etc.

Tabela 10. Consciência crítica a respeito da utilização de serviços ambientais pelas lideranças de São Tomé das Letras, MG.

\begin{tabular}{lcc}
\hline Você acha que causa prejuízo ao meio ambiente? & $\mathbf{N}$ & $\mathbf{\%}$ \\
\hline Sim & 49 & 77,8 \\
Não & 14 & 22,2 \\
\hline
\end{tabular}

Os comentários evidenciaram que essas lideranças ignoram os danos causados pela utilização de bens e serviços comuns, como energia elétrica, habitações, estradas, agricultura, pecuária etc. Isso denota um dos aspectos da visão reducionista sobre a relação homemambiente, que, segundo Morin (2000), é resultado de uma visão de mundo fragmentada pela maneira como a sociedade capitalista se estrutura, o que conduz ao enfraquecimento da consciência e responsabilidade pessoal, à medida que cada um passa a responder somente por sua tarefa especializada:

POD.PUB 4 - Eu acho que sim, porque o único vício que eu tenho é fumar cigarro e eu acho que fumar cigarro é poluidor. É um vício que eu to tentando largar. Tento não jogar guimba de cigarro no chão, essas coisas...

COMUNID 2 - Eu não. Porque eu cuido, cuido dos meus bichos, eu cuido da mata, eu planto árvores. Eu amo a natureza, né. Então eu sempre estou fazendo alguma coisa, pouca, mas faço.

O prejuízo ambiental causado pelas atividades humanas é, inúmeras vezes em nossa sociedade, legitimado por gerar emprego e renda, e pode ser bem exemplificado por duas falas:

MINER 4 - Veja bem, eu até como minerador, eu não acho que eu causo exatamente um prejuízo ao meio ambiente. (...) No meu entendimento eu gosto de falar assim, eu não prejudico o meio ambiente, eu digo que eu o transformo. Eu acho que eu deveria transformar da melhor maneira possível, porque quando eu transformo, eu estou gerando emprego e renda. Se eu gerar emprego e renda e pagar impostos, de alguma maneira eu estou devolvendo para a sociedade um pouquinho daquela transformação que eu estou causando. Agora, tanto vai ser melhor, quanto menos eu transformar, por exemplo, se eu transformar sem degradar o meio ambiente, sem prejudicar nascentes e matas, e desde que eu traga benefícios pra área social, gerando emprego e renda, eu 
acho que eu estou cumprindo com o meu dever de cidadão. Porque de alguma maneira o bem mineral existe e está aí pra ser explorado. Ele não explorado, ele não faz bem pra ninguém. Se ele for mal explorado ele traz prejuízos pra muitos e ganho pra poucos. Acho que a gente tem que buscar uma equação, onde muitos trabalham e todos ganham, desde o patrão, o empregador, os funcionários, a sociedade, o próprio governo (...).

MINER 1 - Eu concilio ser humano e meio ambiente. Não se pode preservar muito o meio e deixar as pessoas, né? Nós devemos conciliar a extração da pedra com a conservação da natureza.

Segundo Bensusan et al.(2006), a compensação ambiental não deve ser vista como um mero pagamento para se obter o direito de destruir. De acordo com essa ideia, o único limite para a exploração ambiental seriam os recursos financeiros do empreendedor. Segundo o autor, o centro da discussão deve ser a concepção de alternativas não apenas monetárias, mas também, possibilidades de modificações nos projetos originais ou mesmo sua não execução.

Representantes do segmento econômico altamente empregador e poluidor no município desviaram o foco da discussão sobre os prejuízos causados por suas empresas para os danos ambientais gerados por atividades domésticas, ou emitiram uma opinião simplista e reducionista a respeito do que venha a ser contaminação. Nos exemplos abaixo, a poluição e perda de hábitat natural, geradas pelos rejeitos de quartzito que são "jogados fora", até mesmo dentro da área urbana da cidade, e que lamentavelmente representam mais de $80 \%$ daquilo que é extraído (FEAM, 2009), ganha contornos menores do que a gerada pelo lixo doméstico e pelo "incômodo", aparentemente inofensivo, atóxico, da poluição visual:

MINER 2 - Minha empresa, apesar de ser um processo controlado, tem resíduos, não são resíduos tóxicos, quentes, mas gera resíduos. Quando eu fico um final de semana em casa - eu gosto muito de cozinhar - eu olho o saco de lixo que produz uma família pequena, é assustador o que a gente produz de lixo. Agora se você multiplica isso por seis bilhões de pessoas no planeta, realmente. Um dia eu estava dando uma palestra sobre isso, aí alguém disse, "Ah, não! Qualquer coisa eu jogo o lixo fora." Não existe esse conceito de jogar fora, o planeta Terra é um sistema fechado, a não ser que se descubra alguma maneira de jogar lixo no espaço, mas enquanto isso não existe, jogar lixo fora, você só vai colocá-lo longe de você. Depois, em algum momento, ele volta.

MINER 1 - A extração de pedra incomoda pela poluição visual, mas não contamina.

Por outro lado, quase $80 \%$ dos entrevistados demonstraram ter consciência do resultado de suas ações diárias no meio ambiente. Uma visão consciente da utilização dos recursos naturais passa pela premissa de que, em algum nível, a exploração de serviços ambientais gera degradação ambiental (BELL, 2001):

AGRIC 4 - ... porque a gente planta, a gente trabalha com máquina, com agrotóxico, pra tudo tem que usar, pra tratar o milho tem que usar, pra plantar o café tem que usar, por sim ou por não, a gente acaba prejudicando o meio ambiente.

RELIG 4 - Eu? Com certeza, todos nós causamos né? A gente tá de carro, a gente acaba poluindo o ar... Mas são coisas inevitáveis. Conscientemente, dizer assim "ah, eu quero destruir o meio ambiente", não, isso não! Agora, de maneira inconsciente e indireta, todos nós poluímos.

$\mathrm{Na}$ última citação o entrevistado retira parte de sua responsabilidade de degradador ambiental ao utilizar a expressão "de maneira inconsciente e indireta, todos nós poluímos". A 
invisibilidade dos danos ambientais gerados pelo ser humano, especialmente na concepção de moradores de grandes centros urbanos, pode ser muito bem exemplificada pela fala abaixo:

TUR/COM 4 - Com certeza, com certeza. Todos os seres humanos causam algum prejuízo. Só da gente existir já causa, porque não tem como, a gente tem esgoto, fossa, lixo. Por mais que assim "ah não, eu reciclo"... Mas você produz, você produz o lixo. Sempre tem o impacto. Às vezes tem pessoas que não tem consciência desse impacto. Tanto que às vezes a gente recebe pessoas que são altamente ecológicas aqui e aí, por exemplo, quando elas veem as pedreiras de São Tomé das Letras, falam "que absurdo!", mas aí a gente meio que põe elas na real: "mas peraí, será que é tão absurdo assim?", e às vezes a gente descobre que tem uma pedra na piscina da pessoa, ou então que ela tem, por exemplo, uma brita que serve pra levantar uma casa, que está vindo de uma montanha. Ou então, ela: "poxa, mas pra onde vocês mandam o esgoto?" e aí eu falo:"você manda o seu pra onde? Pro rio né, que corre no meio da cidade". (...) na cidade maior, o impacto é muito grande, porque aí são milhões de pessoas fazendo a mesma coisa e sem perceber. Porque aqui a gente vê, se você tirar uma fossa e tiver errada, daqui a pouco chega pra mim, então você sente. Em São Paulo você anda na rua, o rio Tietê está ali, o cheiro também você sente, mas você nunca vai falar "pô, isso aqui sou eu que estou ajudando".

Conservar, por quê? A razão principal, segundo os entrevistados, para ações que preservam a natureza, é a manutenção da vida da espécie humana sobre o planeta (Tab. 11). A crença de que é preciso conservar a natureza porque, sem ela, o ser humano não sobrevive foi ressaltada por $76 \%$ dos entrevistados. Esse é um discurso utilitarista e antropocêntrico, que vai ao encontro das motivações básicas para ações efetivas de conservação na atualidade (ROSUMEK, 2009). Segundo esse autor, a força motriz para investimentos em projetos e pesquisas de conservação ambiental baseia-se na justificativa de que dependemos dos recursos naturais e, na ausência deles, não sobreviveremos:

POD.PUB 6 - Porque a preservação da natureza é essencial para a sobrevivência e para perpetuar a humanidade.

EDU 2 - Então, eu acho importante preservar para poder garantir certas necessidades humanas que a gente tem. Se a gente destruir a natureza, no sentido de não conseguir mais ter produção de alimento ou no sentido de não conseguir produzir mais energia, ou mesmo as espécies que a gente costuma conviver... E também preservar porque a gente não conhece muito bem a interdependência que existe entre os seres vivos. Às vezes a gente prejudica uma determinada espécie animal ou vegetal, e aquilo vai causar uma cascata e vai desaguar numa outra que a gente nem imaginava que talvez fosse importante pra gente. 
Tabela 11. Motivações ambientais preservacionistas, segundo as lideranças de São Tomé das Letras, MG.

\begin{tabular}{lcc}
\hline Por que é importante preservar a natureza? & $\mathbf{N}$ & \% \\
\hline Para garantir a sobrevivência humana & 48 & 76,2 \\
Para garantir o desenvolvimento econômico & 8 & 12,7 \\
Pelo seu valor intrínseco & 7 & 11,1 \\
\hline
\end{tabular}

Para Descola (2000), todas as conceituações de meio ambiente se baseiam em um referencial antropocêntrico. Nesse modelo, segundo o autor, a natureza é definida negativamente, como um segmento autônomo que se desenvolve independentemente da ação humana. Já Machado (1996) afirma que o ser humano percebe seletivamente aquilo que Ihe interessa, e o que the é de costume observar, de acordo com seu contexto sociocultural. Aqui, a concepção antropocêntrica utilitarista é bem caracterizada:

MINER 4 - Eu acho extremamente importante preservar o meio ambiente. (...) eu tanto vou conseguir mais, na minha empresa de extração mineral, se eu souber cuidar bem do meio ambiente. Inicialmente, legalmente. Se eu não tiver o registro, os diversos órgãos de controle vão me embargar. Segundo, porque se eu não cuidar bem dele, o negócio não vai ser próspero, não vai ser perene, não vou conseguir trabalhar por um longo tempo.

Segundo Rosumek (2009), uma conotação aparentemente não antropocêntrica, ou um argumento exógeno seria: "a biodiversidade/vida/espécies/ecossistemas/Terra deve ser conservada, pois possui valor intrínseco e merece existir independentemente do seu uso para o humano". A preservação ambiental pelo valor intrínseco esteve presente no discurso de sete entrevistados:

POD.PUB 7 - É aquele jargão né? Manter o que tem aí, e se olhar por outro lado também, é um direito da natureza existir, de ter sua vida, seu sistema, proteger os sistemas ecológicos. Tem o benefício de preservar para o homem continuar usando, mas também pelo direito da existência da própria vida de outras espécies.

As lideranças de São Tomé das Letras foram unânimes em concordar que todos os cidadãos são responsáveis por preservar o meio ambiente (Tab. 12), entretanto, quase $25 \%$ delas reforça que, não apenas todos os cidadãos devem zelar pelo meio ambiente, mas, especialmente, aqueles que mais o degradam e os que representam o poder público:

TUR/COM 4 - Eu acho que é geral, vai desde a administração, a parte turística, a prefeitura, o governo estadual, federal, população, empresas. Aí é uma responsabilidade que tem que ser dividida, não tem como falar que é de um órgão ou de um setor. É que alguns têm uma responsabilidade maior, inclusive porque são pagos pra isso, para poder gerar esses recursos $e$ também administrar. Daí a responsabilidade deles é muito grande. Só que aí passa por toda a população também. Não adianta às vezes você fazer uma administração que faça um trabalho bacana e a população não colabora. 
Tabela 12. A responsabilidade de cuidar do meio ambiente, segundo as lideranças de São Tomé das Letras, MG.

\begin{tabular}{lcc}
\hline De quem é a responsabilidade de cuidar do meio ambiente? & $\mathbf{N}$ & $\mathbf{\%}$ \\
\hline Todos & 48 & 76,2 \\
Todos, especialmente do Poder Público & 10 & 15,9 \\
Todos, especialmente de quem degrada mais & 5 & 7,9 \\
\hline
\end{tabular}

Durante as entrevistas, algumas questões suscitaram reflexões interessantes que levaram a exemplos de atitudes que podem minimizar a degradação ambiental e contribuir para a preservação do meio ambiente:

TUR/COM 8 - Eu acho que hoje, o que mais as pessoas deveriam tentar, é serem antiglobais. Antes todo mundo queria ser global, mas acho que hoje o mais correto para nós é criar algum tipo de equilíbrio... seria o regionalismo, né? Então, eu consumir meu alimento num raio de cinqüenta quilômetros, nunca mais do que isso, ir no mercado e procurar o queijo do meu vizinho, o leite da vizinha, a fruta do meu outro vizinho... eu acho que é isso, antiglobalização mesmo.

Em relação à mineração, a maioria dos entrevistados (90\%) reconheceu sua importância como fonte de renda para o município e para as cidades vizinhas, uma vez que emprega muitas famílias (Tab. 13), e demonstrou preocupação em relação à degradação ambiental que a atividade gera, ou à forma irresponsável com que algumas empresas a realizam. Dentre tais ações irresponsáveis, figuraram a falta de planejamento de lavra para a extração, escassez de iniciativas de restauração das áreas degradadas e extrações ilegais do ponto de vista socioambiental, em que as compensações financeiras oriundas da atividade não chegam ao município:

EXTRAT 5 - A mineração... é a sobrevivência do município de São Tomé. É a maior renda. Mas só que a mineração degrada, e degrada bastante o meio ambiente. (...) 47 anos que eu estou na mineração, alguns conceitos tem que ser revistos porque ainda há muito desperdício. (...) quando eu comecei minerar degradava menos, porque era tudo manual (...), acho até que você minerava com melhor qualidade do que você minera hoje.

CM/O.PUB 4 - Eu acho que mineração é uma tradição. Eu que conheço São Tomé há uns 30 anos, eu sei que de uns 10, 11 anos pra cá, a mineração tomou um rumo inesperado. (...) a partir do momento em que começou a se perceber que a pedra são tomé, o quartzito são tomé poderia ser exportado, uma quantidade grande de empresas vieram, com maquinário pesado e a degradação aumentou muito, quer dizer, o impacto ambiental aumentou muito. Aquilo que era uma tradição de avô, passava de pai pra filho, que era o orgulho de quem sabia tirar pedra, porque era "eu sei fazer isso, eu conheço essa pedra, essa pedra é meu lugar", isso se perdeu em relação à exploração desordenada, e por culpa de alguns prefeitos, que foram abrindo as porteiras, sem impedir que algumas coisas fossem feitas. E eu acho que agora nós estamos numa situação difícil, porque nós damos empregos para muitas pessoas da região vizinha, das cidades vizinhas (...). O maquinário pesado, a quantidade de máquinas, de perfuratrizes, de bombas, isso aqui ficou uma loucura. (...) o extrator continua um coitado, assina férias e não tira, tem carteira assinada, por dois salários mínimos e trabalha por produção. Quer dizer, quando ele fica doente, aqueles 800, 1000 reais que ele tira por produção, por mês, fica reduzido a dois salários e que às vezes não dá nem pra comer. 
Quer dizer, não melhorou pro extrator, e enriqueceu muita gente, que vem aqui com automóvel cabine dupla e roda pra cima e pra baixo...

Tabela 13. $O$ que as lideranças de São Tomé das Letras, MG, pensam a respeito da mineração de quartzito no município.

\begin{tabular}{lcc}
\hline O que você pensa sobre a mineração em São Tomé das Letras? & N & \% \\
\hline Fonte de renda importante & 57 & 90,5 \\
Causadora de intensa degradação ambiental & 57 & 90,5 \\
Descumpridora de normas de compensação ambiental e responsabilidade social & 30 & 47,6 \\
Causadora de silicose & 8 & 12,7 \\
Não é a favor da atividade & 3 & 4,8 \\
\hline
\end{tabular}

Outro motivo de preocupação de alguns entrevistados foi a atuação das mineradoras dentro do perímetro urbano da cidade, ocasionando intensa poluição visual; barulhos das detonações que, muitas vezes, são geradoras das rachaduras nas casas, e o pó da pedra, responsável por grande parte da sujeira na cidade. Um exemplo dessa prática é a atividade de lavra na área denominada Carlos Cardoso, localizada praticamente dentro da zona urbana, na porção oeste da cidade, limitando-se com a Escola Estadual José Cristiano Alves e muito próxima também da Escola Municipal Portal das Letras. O impacto visual dessa área é grande também para quem chega pela estrada asfaltada, que dá acesso a Três Corações. Segundo a FEAM (2009), a atividade de mineração nessa área deverá ser embargada, a área deverá ser interditada definitivamente e recuperada o quanto antes. Uma área muito frequentada pelos turistas no passado, o Vale das Borboletas, também próximo à zona urbana da cidade, está bastante assoreado por finos de lavra e rejeitos de pedra.

Em relação ao impacto dos rejeitos para a cidade, a FEAM estima que a produção bruta do município tenha somado 1,3 milhões de toneladas em 2008, com recuperação média de lavra de $30 \%$, ou seja, 900 mil toneladas de rejeito foram produzidas em 2008 , sendo que $80 \%$ desses rejeitos foram dispostos nas frentes de lavras e $20 \%$ nas plantas de beneficiamento fora do município. Assim sendo, 720 mil toneladas de rejeito foram acumuladas nas serras da região apenas no ano de 2008. Estima-se que 26,7 milhões de toneladas de rejeitos tenham sido acumulados no município de São Tomé das Letras desde a década de 1950 (FEAM, 2009). Muitas vezes as pilhas de estéril são depositadas sobre os corpos de minério, necessitando de posterior remobilização, uma prática resultante da falta de levantamentos topográficos e geológicos nas minas (VIANA e BURSZTYN, 2010). Outro problema sério é o assoreamento de corpos d'água por rejeitos de pedra, como o ribeirão Passa Quatro, a sudoeste da cidade, em cuja área de influência são desenvolvidas atividades de lavra (FEAM, 2009). Na tentativa de mascarar a sensação de degradação, revertendo-a para de encantamento, algumas pousadas da cidade batizaram a vista das cavas e das pilhas das pedreiras de "paisagem lunar" ou "picos nevados".

Chiodi-Filho (2006) considera que a adequação ambiental da atividade de lavra de quartzito está condicionada mais à diversificação dos produtos comerciais da pedra e ao aproveitamento de seus resíduos como matéria prima de uso industrial, do que a modificações nas técnicas de desmonte. Segundo esse autor, os mineradores tradicionalmente atuam por produção e não por produtividade, portanto, o volume de estéril produzido pela mineração 
continua muito elevado porque o uso de explosivos não poderia ser dispensado no desmonte do material mais resistente.

Quase metade dos entrevistados ressaltou que praticamente inexiste compensação ambiental ou social na cidade (Tab. 13) e denunciaram o exercício da atividade dentro da ilegalidade, uma vez que muitas empresas negam-se a emitirem notas fiscais, sonegando impostos. Esses relatos foram feitos em tons de revolta, de crítica e indignação:

TUR/COM 1 - São Tomé é saqueado há mais de 50 anos porque as pedras saem de São Tomé sem nota fiscal e vão pros depósitos de Três Corações, Caxambú, Baependi e Cruzeiro, em Conceição do Rio Verde. Lá sim, é bem faturado; a pedra é cortada, é lixada, é polida e é feita a nota fiscal de exportação. Então, toda riqueza de São Tomé fica nas cidades vizinhas.

CM/O.PUB 2 - Acharam a pedra, que é exportada, comercializada pra outros estados, exportam e vivem disto. Agora não tem como mais parar. Tem a sonegação de impostos. Essa nota vai e volta carimbada várias vezes. Não tem fiscalização. Tem preço de pedra que não é verdade, o metro tá 30,40 reais, sai daqui a um real o metro.

TUR/COM 3 - O valor agregado da pedra, aquilo que traz maior valor agregado, fica nas outras cidades, onde se faz o beneficiamento. (...) Pasme, eu entrei há um tempo atrás em um site do IBGE e, pasme, que a atividade principal de São Tomé das Letras consta como sendo a atividade agrícola, a agropecuária, e não a extração mineral! Quando na verdade nós sabemos que 65\% ou $70 \%$ da atividade econômica do município é da pedra... então, o que está havendo gente??

De fato, os dados fornecidos pelo entrevistado acima podem ser verificados na página virtual do Instituto Brasileiro de Geografia e Estatística (IBGE, 2011), que reúne informações sobre os indicadores socioeconômicos dos municípios mineiros, dentre outras. Segundo o IBGE, as atividades econômicas do município de São Tomé das Letras restringem-se às agrícolas e de pecuária. Em contraposição, o documento produzido pela FEAM (2009) relata que o Arranjo Produtivo Local de São Tomé das Letras é constituído por 110 empresas formais e 80 empresas informais, responsáveis por cerca de 6.000 empregos, nas atividades de lavra, beneficiamento, comércio e serviços. $O$ documento estima que os negócios relativos à pedra São Tomé, incluindo serviços, estejam movimentando de 60 a 70 milhões de dólares por ano, no mercado interno e externo, sendo que $65 \%$ da produção destinam-se ao estado de São Paulo e da região sul, e $20 \%$ à exportação.

Atualmente, as frentes de lavra do município distribuem-se de NE-SW pelos locais denominados Pico do Gavião, Carimbado, Cooperativa dos Extratores de Pedras do Patrimônio de São Tomé das Letras, a COOPEDRA, com 82 empresas atuando numa área reduzida de 48,5ha, Chapadão e Paredão (FEAM, 2009). Segundo a FEAM, algumas melhorias foram verificadas na atividade minerária desde a atuação do órgão no município, iniciada em 1992/93: desenvolvimento planejado da lavra e definição de áreas para construção das pilhas de rejeito; construção de bacias de contenção de finos e de muros de proteção na base das pilhas, que reduzem o assoreamento dos cursos d'água; fixação de horários pré-estabelecidos para as detonações nas frentes de lavra e a revegetação das pilhas de rejeito. A recuperação final da lavra foi melhorada, a partir de 2001, com a diversificação dos produtos comerciais de ornamentação e revestimento, e com o aproveitamento final da lavra e seus rejeitos como matéria prima de uso industrial e na construção civil (tintas, argamassas, massas corridas, areia, brita etc.) (FEAM, 2009). 
Tais medidas foram tomadas pelos mineradores face à necessidade de regularização ambiental a que foram submetidos os seus empreendimentos. No entanto, convém destacar que esses dados produzidos pela FEAM são provenientes de um estudo da situação de 31 empresas com processos ativos no Departamento Nacional de Produção Mineral (DNPM), e com prazos de Licença de Operação (LO) e Autorizações Ambientais de Funcionamento (AAFs) vigentes junto ao Conselho Estadual de Política Ambiental (COPAM). Ou seja, os dados refletem a situação de uma minoria atuante na mineração de quartzito em São Tomé das Letras. Acredita-se que os produtores informais são responsáveis por grande parte dos problemas ambientais, fiscais e trabalhistas existentes, uma vez que escapam aos mecanismos institucionais de controle legal (FEAM, 2009; VIANA e BURSZTYN, 2010). Uma operação do Sistema Estadual de Meio Ambiente e Recursos Hídricos (Sisema) fiscalizou 68 mineradoras em São Tomé das Letras e Luminárias, em dezembro de 2011, e constatou irregularidades em 36 delas, sendo que 18 foram autuadas com multas e suspensão de atividades. Dentre as irregularidades, foram detectadas intervenções em Áreas de Preservação Permanente (APPs). De acordo com a equipe técnica que participou da fiscalização, "a atividade minerária de quartzito nos municípios de São Tomé das Letras $e$ Luminárias é extremamente predatória e necessita de um acompanhamento técnico pontual, principalmente quanto à destinação dos rejeitos e passivos da atividade minerária." (SEMAD, 2011).

Ainda segundo a FEAM (2009), a arrecadação da Compensação Financeira pela Extração Mineral (CFEM) em São Tomé das Letras é muito baixa, pois ela só é recolhida pelas empresas regulares e, mesmo assim, muito abaixo do esperado, mesmo tendo aumentado a partir de 2004 ( $R \$ 39,2$ mil) e atingindo seu máximo em 2007 ( $R \$ 173,8$ mil). Em 2008 teve queda de quase 16\%, em função da crise econômica mundial. Esse ônus ambiental da mineração constitui uma fonte constante de desentendimento entre prefeitura e mineradores.

Ao deixarem de incorporar o tema responsabilidade ambiental em seus planos de ações, as empresas fomentam riscos à sua atividade econômica como "questionamento de sua licença para operar, ruptura de sua cadeia de suprimentos, danos à imagem de sua marca, boicote por parte dos consumidores, multas, baixo desempenho e valor nos mercados financeiros, entre outros" (ALMEIDA e BULHÕES, 2006). Contrariamente, segundo esses autores, ao lidarem com as questões ambientais de maneira séria, as empresas podem "abrir novo campo de oportunidades, como maior credibilidade pública, maior reputação de sua marca, redução de custos com ações de remediação e a lealdade dos investidores, além de outros valores intangíveis e tangíveis".

Sabe-se que os custos ambientais de atividades mineradoras, na maioria dos casos, são inferiores aos de outras atividades degradantes e, pela legislação ambiental, já devem ser incluídos no cálculo da viabilidade econômica da jazida. Entretanto, segundo Viana e Bursztyn (2010), existe um importante motivo para a alta inadimplência socioambiental e trabalhista, consequentemente, menor rentabilidade, de mineradoras clandestinas: uma área de mineração paralisada torna-se um passivo ambiental de difícil reparação. Para tentar sanar esse problema, surgiu o Termo de Ajustamento de Conduta (TAC), que permite a continuidade das atividades minerárias concomitantemente ao processo de regularização, mediante a "promessa" de uma série de medidas, muitas vezes não cumpridas (VIANA e BURSZTYN, 2010).

Mais de $20 \%$ das lideranças lembraram que a extração de pedra e seu beneficiamento empregam muitas pessoas de cidades vizinhas (Tab. 13), fato este que alguns entrevistados utilizaram para questionar a real dependência dos moradores de São Tomé das Letras, um município com potencial turístico reconhecido nacional e internacionalmente, em relação às atividades de mineração: 
RELIG 6 - A maioria do povo que trabalha nas pedreiras não é daqui, são das cidades vizinhas, Três Corações, São Bento Abade, Conceição do Rio Verde, Cruzeiro e Baependi. Eles vêm, trabalham, ganham um dinheirinho e vão embora. De manhã vêm os ônibus trazendo esse povo e à tarde os leva de volta para suas cidades. Então, esse povo não deixa lucro nenhum para São Tomé das Letras. Agora, a coisa que eu mais acho terrível é que os impostos das pedras são muito lesados, quando se tira a nota fiscal das pedreiras que geram esses impostos, ao invés de ficarem em São Tomé das Letras, eles vão para as mãos das cidades vizinhas porque é lá que eles emitem a nota definitiva. Lá eles podem fazer o acabamento na pedra, seja serrar as pedras ou às vezes até polir, de lá pra frente que eles vão tirar as notas fiscais para as pedras, que vão principalmente pra São Paulo e outros estados, as pedras de São Tomé vão até para o exterior. Esses impostos, ao invés de ficar para o município de São Tomé, vão para as cidades vizinhas que têm prosperidade com isso, nós ficamos com os ossos das pedras, que são essas sujeiras que ficam nessas montanhas, ao redor da cidade e até dentro da cidade.

Apesar destas considerações, apenas $5 \%$ dos entrevistados foram declaradamente contra a extração de quartzito (Tab.13). Os motivos pelos quais essas lideranças se posicionaram contra estão bem explicitados nas falas abaixo:

COMUNID 4 - Eu acho desnecessária. Não é um minério super necessário para a vida das pessoas, a indústria deve usar do meio ambiente o mínimo possível. Eu acho que é tão desnecessária pedra para beira de piscina, ou para fazer fachada de casa, então eu sou realmente contra, poderia preservar essa montanha que seria melhor.

RELIG 4 - A mineração é aquilo que o povo fala, né? Um mal necessário... Atualmente, é fonte de renda, de lucro... pros empresários! Pro povo, não! Se tivesse como direcionar essas pessoas que trabalham na mineração, que cuidam das suas famílias com o ganho do seu trabalho, pra uma atividade que não agredisse tanto a natureza, no caso o turismo, que é a riqueza maior da nossa comunidade, do nosso povo, do nosso município, seria ótimo! Agora, os grandes empresários é que vão chiar. A gente sabe como funciona isso no nosso país: interesses financeiros e econômicos estão acima dos interesses humanos.

RELIG 2 - Olha, eu acho que mineração já deu o que tinha que dar aqui, sabe. Mal dá o sustento pros trabalhadores da cidade. (...) vai deixando o homem muito duro, homens com 40 anos de idade, que você olha e tá com cara de 70, judiados pelo sol. Tem a questão também do pó da pedra, que em tempos passados não era tanto, mas agora já tá dando muito problema e no futuro vai dar muito mais. Porque o pó dessa pedra, agora não, porque nós estamos na época da chuva, mas na época da seca, você deixa o carro pra fora de casa, em questão de 4 horas seu carro tá branco. Quer dizer, tá fazendo mal, não só pro trabalhador, mas pra população toda... E eu tenho certeza que no futuro, já que não demora, grande parte da população vai começar a ter problema respiratório, porque realmente o negócio tá demais. Vocês não têm noção. É um negócio que tá sendo levado na ganância mesmo. A mineração, eu acredito, já devia ter parado. Porque a população, além de ficar doente, tá sendo explorada, que na verdade, o que já saiu de pedra daqui, era pra ser uma cidade com mais riquezas. E continua sendo uma cidade pobre, onde só alguns realmente estão se dando bem. Então, eu acredito que, por mim, eu acredito que já era pra parar. 
Apenas oito entrevistados levantaram o gravíssimo problema da silicose (Tab. 13), uma fibrose pulmonar causada pela inalação de poeiras contendo dióxido de silício $\left(\mathrm{SiO}_{2}\right)$ no estado livre, a chamada sílica livre cristalina (PNES, 2001). É uma pneumopatia ocupacional que representa um grave problema de saúde pública, especialmente em países subdesenvolvidos ou em desenvolvimento, como é o caso do Brasil (ALGRANTI et al., 2003). A silicose é relatada há muitos séculos, é incurável e por isso considerada a mais grave doença pulmonar relacionada à inalação de poeiras minerais. Leva alguns anos para se manifestar, podendo ocasionar incapacidade para o trabalho, invalidez, suscetibilidade para turberculose e óbito (PNES, 2001). Seu diagnóstico é baseado em radiografia de tórax e história clínica (BARBOSA et al., 2011). A Agência Internacional de Pesquisa sobre o Câncer (IARC) da Organização Mundial da Saúde considera a sílica livre cristalina inalada, uma substância cancerígena.

As exposições à poeira de sílica são mais evidentes nas atividades de beneficiamento, como serragem e polimento. A subdelegacia da Delegacia Regional do Trabalho estimou que a população total exposta à poeira de sílica no mercado formal de São Tomé das Letras, excluindo o setor administrativo, é de 1200 empregados para a extração e 800 para o beneficiamento (BARBOSA et al., 2011). Segundo os autores, foram encontradas imagens compatíveis com silicose em $25 \%$ das radiografias do tórax de 186 extratores e beneficiadores, incluindo três portadores de grandes opacidades e oito com formas avançadas da doença. Sabendo, portanto, que esta patologia configura um problema seriíssimo para o município, foi pouquíssimo lembrada pelas suas autoridades:

RELIG 6 - Um vizinho meu está com areia no pulmão e ele fala que não tem jeito, ele vai para Belo Horizonte e diversos lugares para tratamento, mas eles acham que não tem recurso, então o recurso é a morte mesmo. Principalmente quando eles vão perfurar a pedra pra colocar o explosivo, aquela areia muito fininha que sobe, às vezes penetra e vai para o pulmão, e mistura aquela areia na pleura, contaminando muito o povo. Mas seja como for, é uma das opções pra pessoa ganhar o seu dinheiro e cuidar da família, agora eu penso que eles têm pouco retorno de um serviço tão árduo (...). Os que lucram com as pedreiras são os que pagam o povo daqui para tirar as pedras.

De acordo com o estudo de Barbosa et al., (2011), realizado em São Tomé das Letras, "além da exposição à sílica, os trabalhadores enfrentavam também outros riscos, como ruído, vibração, exposição por longas horas à luz solar, adoção de posturas inadequadas, risco de explosões e desmoronamentos. Uma característica observada também marcante do perfil deste trabalho na região é a alta rotatividade da mão de obra dos trabalhadores, que migram para outras empresas também de extração ou beneficiamento".

As exigências legais para extração da pedra foram apontadas com críticas por alguns entrevistados, especialmente por mineradores, que discutiram a ausência de uma política clara que regulamente suas atividades, uma vez que vários órgãos estão envolvidos, com exigências e cobranças diferentes:

MINER 2 - Nós barramos uma coisa terrível que é a morosidade e incompetência do Estado sobre a produção de leis, pra você ter uma ideia, nós estamos subordinados a mais de 25 anos de Estado, cada um te pede uma coisa, uma legislação, cobra taxas, então é um verdadeiro samba do crioulo doido, você não consegue entender. E agora o Ministério Público acha que é o quarto poder e quer mandar no mundo, então o que acontece, a mineração precisa se atualizar, mas essa política 
cambial tirou muito, nós estamos muito descapitalizados e quem cuidou até hoje da parte ambiental consegue dar andamento, mas quem não cuidou não vai sobreviver fácil não. Mas, eu acho que ela é imprescindível para São Tomé, é uma relação, digamos que, siamesa, a cidade com a mineração.

Um problema quanto à regularização das atividades minerárias em geral refere-se à Autorização Ambiental de Funcionamento ( $A A F$ ), que constitui uma nova modalidade de regularização ambiental instituída pelo Estado em 2007, destinada às atividades de menor porte e menor potencial poluidor. Essa exigência exclui a necessidade de apresentação de estudos ambientais, sendo assim, o órgão ambiental corre o risco de autorizar empreendimentos de menor porte em locais e condições inadequadas. A AAF tira as empresas da clandestinidade e reduz a burocracia típica dos processos de licenciamento ambiental, mas não assessora as empresas em suas operações cotidianas. Como fator complicador, a AAF não se encaixa no procedimento fixado há anos pelo DNPM e FEAM para o licenciamento de minerações, a ponto de, em 2007, o DNPM não aceitar a AAF como documento válido para concessão de portaria de lavra (VIANA e BURSZTYN, 2010).

Um breve panorama atualizado das ações de fiscalização ambiental em Minas Gerais foi realizado por Viana e Bursztyn (2010). Segundo os autores, a maioria dos policiais do Comitê Gestor de Fiscalização Ambiental Integrada (CGFai), responsável pela fiscalização das atividades de mineração no Estado, não tem a formação técnica e experiência necessária para aferir o bom andamento das atividades minerárias. Mesmo contando com a atuação de 1200 homens distribuídos em 13 companhias especializadas em meio ambiente e trânsito, no ano de 2006 apenas $6 \%$ do total dos empreendimentos minerários foram fiscalizados pelo CGFai, sendo que 78\% das licenças prévias emitidas pelo Conselho de Política Ambiental (COPAM), até julho de 2006, referiam-se a minerações. De acordo com os autores deste trabalho, "...salta aos olhos a incapacidade de pelo menos acompanhar, ainda que por amostragem, os dados periodicamente enviados pelas empresas de mineração. Os relatórios técnico-fotográficos de cumprimento das condicionantes só são desarquivados, na maioria das vezes, pela superveniência de fato especial (acidente ambiental, denúncia da comunidade, solicitação do Ministério Público etc.)". O artigo cita São Tomé das Letras como exemplo de mau planejamento de lavra de minerais não metálicos com menos valor agregado, e faz uma crítica ao não funcionamento do Relatório de Avaliação de Desempenho Ambiental (Rada) como instrumento de auditoria ambiental no município.

Por fim, quando arguidas sobre o que pensam do turismo em São Tomé das Letras, 60\% das lideranças consideraram-no uma fonte de renda importante para muitas famílias (Tab. 14), embora mal estruturado e carente de infraestrutura. 0 enorme potencial natural e cultural do município foi ressaltado por $56 \%$ dos entrevistados:

POD.PUB 7 - O turismo em São Tomé tem um potencial violentíssimo. Mas ele é muito mal direcionado, entende? (...) em questão dos guias turísticos, um querendo dominar o outro, não tem aquela visão cooperativa de pensar junto no crescimento. Teve uma lei no turismo totalmente equivocada também, na minha opinião, pegaram o modelo de gestão de turismo de Bonito $e$ botaram para São Tomé, aquela coisa pra não se cumprir (...).

O misticismo como atrativo da cidade também foi tema bastante citado pelos entrevistados (Tab.14). Segundo Silveira (2004), o turismo religioso popular configura-se como 
uma oportunidade de mercado, sendo a atração de turistas pela ambiência mística de São Tomé das Letras, um exemplo dessa prática social:

EDU 1 - ... e o próprio misticismo, que cientificamente tá comprovado, tudo existe por causa da energia telúrica, nós estamos sobre uma montanha de $98 \%$ composta de cristal. Então já tem a tendência daquele magnetismo natural. Quer as pessoas creiam ou não, o mais forte do turismo aqui ainda é o misticismo. Porque os locais de montanha são os locais mais altos né, onde os seres humanos podem estar próximos de Deus, assim, entre aspas, né.

Para outros, o maior potencial turístico do município está nas belezas naturais que compõem sua paisagem, assim como nas construções históricas de pedra, e não no misticismo, que contrasta com a vida típica dos nativos do interior de Minas Gerais, cuja religiosidade é basicamente fundida ao catolicismo:

RELIG 4 - Este misticismo, às vezes esoterismo, falar que a cidade é energética, não sei... a gente tem que respeitar, é coisa deles. É uma cidade como todas as outras. O mérito da nossa cidade não tá nisso. O mérito dessa cidade, (...) o potencial turístico dela tá nessa riqueza natural. Tem matas lindas, flores exuberantes, super exóticas até, lindíssimas né? Cachoeira... que tá acabando, infelizmente.

Tabela 14. O que as lideranças de São Tomé das Letras, MG, pensam a respeito do turismo no município.

\begin{tabular}{lcc}
\hline O que você pensa sobre o turismo em São Tomé das Letras? & N & \% \\
\hline Fonte de renda importante & 38 & 60,3 \\
Município com grande potencial natural, cultural, místico & 35 & 55,6 \\
Atividade mal estruturada, mal gerenciada & 31 & 49,2 \\
Apresentou melhora nos últimos anos & 20 & 31,7 \\
Associado a drogas, depredação e perda de identidade dos nativos & 16 & 25,4 \\
Possui relação importante com a mineração de quartzito & 9 & 14,3 \\
\hline
\end{tabular}

O uso descontrolado de drogas, lícitas e ilícitas, foi considerado por $1 \frac{1}{4}$ dos participantes como responsável pela imagem de permissividade que a cidade carrega (Tab. 14). Ao suscitarem essa questão, os entrevistados relacionaram sua origem a fatos que remontam ao passado e explicitaram seu desejo de que outro tipo de turista frequente o município. Cerca de $32 \%$ dos entrevistados relatou ter identificado melhorias do turismo da região, especialmente quanto à chegada de um novo turista, com poder aquisitivo mais alto, com hábitos mais educados, um turismo mais familiar:

CM/O.PUB 4 - O turismo em São Tomé tem muitas fases... A fase do turismo esotérico foi muito interessante. Muita gente vinha pra cá pra procurar essa vibração diferente que tem na cidade, que tem mesmo, ela é muito diferente. (...) Depois passou essa fase do turismo esotérico, veio um monte de hippie, aí veio um monte de gente que não tinha um tostão, muita gente que dizia que era turista... O cara vinha de camiseta, calção, dois contos no bolso e ia comer na padaria. Quer dizer, um turista que não interessa pra ninguém. Só pra depredar, enfim, era o fim da picada. Hoje em dia a gente tem visto vários ônibus, com pessoas de terceira idade, famílias visitando. Muito 
mais pra vir almoçar, passar o dia, ir pra cachoeira, que especificamente pra ficar na cidade, né. Nós podemos transformar essa cidade numa coisa muito boa, do ponto de vista turístico, se houvesse uma programação séria, bacana, padronizada.

EDU 4 - Ah, eu acho que tá precisando investir em outro tipo de turista, sabe? Que esses turistas que vem, pela própria fama que ficou de droga, de rock... o povo chama de "durista", que só vem aqui pra aprontar, encharcar. Os místicos antes vinham muito mais, pararam bastante de vir. Parar com pousadinha... Qualquer quartinho vira uma pousadinha, como eles dizem, de 1,99. Eles dormem em qualquer lugar. Acampam em qualquer lugar. Aprontam! Então, quando é época de feriado... eu fujo. Aumenta a violência, aumenta tudo. Acho que eles deveriam investir em propaganda, porque São Tomé é uma cidade mística. E não uma cidade de drogados, de bebida, de farra, de cair na pirambeira.

Apenas $14 \%$ das lideranças lembrou a importância de se conciliar ambas as atividades, turismo e mineração (Tab.14), em prol do desenvolvimento econômico e social da cidade:

CM/O.PUB 3 - Como eu já disse, nós não sobrevivemos sem a mineração. Tem uma metade que sobrevive do turismo e outra metade que sobrevive da pedra. Não tem estudos estatísticos sobre isso, mas penso eu que precisa dos dois pra São Tomé se manter. Então, o que precisa fazer? Hoje, como se fala, ter uma exploração sustentável das minerações e cuidando do meio ambiente, que é o principal.

De acordo com Marques-Neto (2008), um exemplo claro de exploração turística mal planejada em São Tomé das Letras encontra-se presente na Gruta de Sobradinho, localizada na vertente oeste da Serra do Sobradinho. O expressivo número de pessoas que a gruta recebe para visitação, sem nenhum tipo de restrição ou controle, especialmente nos feriados, resulta em depredações típicas dessa atividade, como lançamento de lixo pelos visitantes e pichações nas paredes da gruta. Segundo o Centro Nacional de Pesquisa e Conservação de Cavernas (CECAV), criado pela Portaria N. 78, de 3 de setembro de 2009, a conservação dos ambientes cavernícolas e suas espécies associadas deve ser embasada em plano de manejo (DIÁRIO OFICIAL DA UNIÃO, 2009), entretanto, pouquíssimas cavernas o possuem.

Por sua vez, a falta de planejamento de lavra atinge áreas cavernícolas com pinturas rupestres sem qualquer estudo e proteção. Um exemplo constrangedor encontra-se na fachada da pousada Mirante das Pedras, na Praça do Rosário, onde uma pintura rupestre, encontrada em um fragmento de rocha em área de mineração, foi levada por um morador e assentada na fachada, há dez anos (Fig. 2D).

Os entrevistados mostraram-se insatisfeitos também com a falta de estrutura da cidade para receber, em suas áreas naturais, pessoas idosas ou de meia idade, uma vez que o turismo familiar tem crescido no município. Apontaram a carência de placas explicativas e sinalizadoras para que o turista compreenda o que vê e saiba como chegar ao destino de seu interesse. Reclamaram das poucas lixeiras nas ruas e da sujeira da cidade em época de festas, especialmente na região central. 


\section{CONCLUSÕES}

Este trabalho permitiu observar que as lideranças de São Tomé das Letras possuem, em geral, conhecimento crítico a respeito de temas importantes para a cidade, como aqueles relativos à mineração de quartzito e ao potencial turístico da região, temas esses que remetem fortemente à problemática ambiental do município. No entanto, verifica-se que as razões conservacionistas dos entrevistados são antropocêntricas e utilitaristas, ou seja, é preciso conservar o ambiente natural, na opinião dos mesmos, porque o ser humano depende dele para sua sobrevivência. Essa percepção pode ser visualizada, por exemplo, na forma como vem sendo conduzida a extração de quartzito, em que os prejuízos ambientais são, em grande parte, "justificados" pelos (supostos) benefícios econômicos e sociais. Por outro lado, percebe-se um desconforto geral dos entrevistados em face dos prejuízos à qualidade de vida dos moradores, advindos da atividade econômica que mais emprega na região. Esse desconforto pode ser muito bem ilustrado pela expressão "a mineração é um mal necessário para São Tomé das Letras", bastante ouvida durante a realização deste trabalho.

Os elementos que figuram no imaginário dos entrevistados e constituem, para eles, a identidade do município, são a pedra, o homem e a natureza. Aplicando esses conceitos para o contexto econômico da cidade, temos a mineração, o turismo, e também, o morador e o meio em que ele se encontra, meio de onde retira o seu sustento, desfruta de momentos de lazer e participa da vida em comunidade. A partir do que foi dito pelos entrevistados e visto nos trabalhos de campo, fica claro que a qualidade de vida dos moradores de São Tomé das Letras depende, intrinsecamente, de um diálogo transparente entre os indivíduos que exploram o potencial econômico da pedra, e aqueles que exploram o potencial turístico das belezas naturais da região.

Em relação à mineração, foi visto que o futuro do Arranjo Produtivo Local de São Tomé das Letras está fundamentalmente ligado à adequação ambiental da atividade produtiva, e uma das demandas mais importantes diz respeito ao aproveitamento dos rejeitos de quartzito para fins industriais. A forma como vem sendo conduzida a mineração da pedra na região, onde muitas empresas não chegam a aproveitar $20 \%$ daquilo que extraem, não é apenas ambientalmente insustentável, mas também, economicamente inviável a longo prazo. O quartzito extraído e não beneficiado, ao sair do município, possui baixo valor agregado, ou seja, não deixa riquezas para a cidade, especialmente porque muitas empresas atuam na clandestinidade. A arrecadação de impostos e o número de empregos tende a aumentar, portanto, não somente por meio da regularização e fiscalização das empresas mineradoras, mas também, por via do beneficiamento da pedra, que poderia ser preferencialmente realizado na própria cidade. Os pequenos mineradores irregulares devem ser assessorados tecnicamente pelo Poder Público, pois mesmo que os órgãos ambientais fiscalizadores atuem com competência, não há garantia de que as empresas melhorarão a qualidade de suas atividades. São necessários investimentos variados e contínuos.

Fica clara também a insatisfação dos entrevistados perante o mau aproveitamento do potencial turístico da cidade. A questão turística de São Tomé das Letras é complicada porque é diretamente afetada pela mineração mal planejada, a começar pelo grande impacto visual que as áreas de lavra causam aos olhos dos visitantes, na entrada e mesmo dentro da cidade.

Muitas outras medidas emergenciais podem e devem ser adotadas no município, com o intuito de melhorar a vida de seus moradores. A paralisação das atividades de frentes de lavra nos limites da área urbana da cidade, assim como a restauração das áreas degradadas por essas mineradoras é urgente. Novas unidades de conservação devem contemplar tanto áreas verdes 
próximas à zona urbana, quanto áreas de cavernas ricas em pinturas rupestres, e provavelmente, ricas também em animais cavernícolas. O Plano Diretor deve indicar formas de ocupação do solo, considerando a implantação de um distrito industrial longe do perímetro urbano. E todos os grupos sociais de São Tomé das Letras devem ser alvo permanente de projetos de educação ambiental e patrimonial. Projetos que contemplem o ambiente e o indivíduo em sua totalidade: sua história, seus saberes, suas percepções e desejos para o futuro.

\section{AGRADECIMENTOS}

À Fundação Centro Tecnológico de Minas Gerais (CETEC/MG), Universidade Federal de Minas Gerais (UFMG), Fundação de Amparo à Pesquisa de Minas Gerais (FAPEMIG), Conselho Nacional de Desenvolvimento Científico e Tecnológico (CNPq) e US Fish and Wildlife Service pelo apoio financeiro e logístico; Dr. Marco Antônio de Rezende (Escola de Arquitetura/UFMG) pelo apoio aos projetos; Dr. João Gabriel Teixeira (Departamento de Ciência Política/UFMG) pelo apoio metodológico para a realização das entrevistas; ao técnico José Carlos dos Santos e à bolsista de IC Bruna Braccini pelo auxílio nos trabalhos de campo, MSc. Carla Alfonsina D’Auria e Ana Maria Sigaud pelo auxílio na inserção na comunidade. A todos os entrevistados que se dispuseram a colaborar com essa pesquisa.

\section{REFERÊNCIAS BIBLIOGRÁFICAS}

ALGRANTI, E.; CAPITANI, E. M.; CARNEIRO, A. P. S.; SALDIVA, P. H. N. Patologia respiratória relacionada com o trabalho. In: MENDES, R. (Org.). Patologia do trabalho. 2. ed. Rio de Janeiro: Atheneu, 2003. p.1329-1397.

ALMEIDA, F. BULHÕES, B. Empresas na rede da sustentabilidade. In: BENSUSAN, N., BARROS, A. C.; BULHÕES, B.; ARANTES, A. (Orgs.) Biodiversidade: para comer, vestir ou passar no cabelo? Para mudar o mundo! São Paulo: Peirópolis, 2006. p.320-337.

BACHELARD, G. A Poética do Espaço. Martins Fontes. São Paulo, Brasil, 1993. 242p.

BARBOSA, M. S. A.; CARNEIRO, A. P. S.; MACIEL, J. G. F. S.; MORONTE, E. A.; LA ROCCA, P. F.; SANTOS, A. R. M. Silicose em trabalhadores de quartzito da região de São Tomé das Letras - Minas Gerais: dados iniciais indicam um grave problema de saúde pública. Revista Brasileira de Saúde Ocupacional, São Paulo, v. 36, n.123. 2011. p.177-184.

BELL, S. Landscape pattern, perception and visualisation in the visual management of forests. Landscape and Urban Planning, v. 54, 2001. 201-211p.

BENSUSAN, N.; BARROS, A. C.; BULHÕES, B.; BARRETO-FILHO, H. T. O futuro, a quem pertence? In: BENSUSAN, N., BARROS, A. C.; BULHÕES, B.; ARANTES, A. (Orgs.) Biodiversidade: para comer, vestir ou passar no cabelo? Para mudar o mundo! São Paulo: Peirópolis, 2006. p.407-418.

BERGSON, H. Matéria e Memória. Martins Fontes. São Paulo, Brasil, 1999. 291p.

CARMO, P. S. Merleau-Ponty: uma introdução. 2. Ed. São Paulo: EDUC, 2011. 153p.

CHIODI, D. K. Os quartzitos de São Tomé das Letras, Minas Gerais: principais demandas para o desenvolvimento sustentável da atividade produtiva. Seminário sobre Arranjos Produtivos de Base Mineral. Brasília, DF: Ministério de Minas e Energia, 2003. 9p.

CHIODI-FILHO, C. Detalhamento de APLs de Base se Mineral - Quartzitos São Tomé das Letras, 2006.

D'AURIA, C. A. São Tomé das Letras na encruzilhada das fontes, dos tempos e dos saberes: um estudo sobre etnografia e historicidade com registros audiovisuais. Dissertação de mestrado. Departamento de Multimeios, Instituto de Artes, UNICAMP, 2000. 431p.

DEL RIO, V.; OLIVEIRA, L. Percepção ambiental. A experiência brasileira. São Paulo: Nobel, 1999. $256 \mathrm{p}$.

DESCHAMPS, E.; MAIA JUNIOR, B.; COSTA, C. S.; SANTOS, M. G. V.; SCHWABE, W. K. ; CARVALHO FILHO, C. A.; DAMASCENO, M. A. P.; PINTO, C. L. L. Controle Ambiental na Mineração de Quartzito São Tomé. 1. ed. Belo Horizonte, MG: Projeto Minas Ambiente, 2002. 201p. 
DESCOLA, P. Ecologia e Cosmologia. In: DIEGUES, A. C. (Org). Etnoconservação: novos rumos para a proteção da natureza nos trópicos. São Paulo. Hucitec, 2000. p.149-163

DHÂRANÂ - Órgão Oficial da Sociedade Teosófica Brasileira; ano XXXII, julho/outubro de 1957, n. 3 e 4. Revista bimestral: Avenida Liberdade n. 47, 1 andar, SP). In: D'AURIA, C. A. São Tomé das Letras na encruzilhada das fontes, dos tempos e dos saberes: um estudo sobre etnografia e historicidade com registros audiovisuais. Dissertação de mestrado. Departamento de Multimeios, Instituto de Artes, UNICAMP, 2000. 431p.

DIÁRIO OFICIAL DA UNIÃO. № 170, 4 de setembro de 2009. Portaria N. 78, de 3 de setembro de 2009. Resolve criar o Centro Nacional de Pesquisa e Conservação de Cavernas - CECAV, sediado em Brasília, no Distrito Federal.

DIAS, G. F. Educação ambiental: princípios e práticas. São Paulo: Gaia, 2000. 551p.

DNPM. Departamento Nacional de Produção Mineral. Disponível em www.dnpm.gov.br. Acessado em 6 de novembro de 2011.

DRUMMOND, G. M., MARTINS, C. S., MACHADO, A. B. M., SEBAIO, F. A. ANTONINI, Y. Biodiversidade em Minas Gerais: um atlas para sua conservação. 2 ed. Belo Horizonte, MG: Fundação Biodiversitas, 2005. 222p.

FARIAS, M. N. Natureza, tempo livre e administração social: uma análise das práticas de lazer em Carrancas, MG. Tese de Doutorado. Universidade Estadual Paulista Júlio de Mesquita Filho, Araraquara, SP, 2008. 124p.

FEAM. Fundação Estadual do Meio Ambiente. Plano de ação para a sustentabilidade do setor de rochas ornamentais - quartzito, São Tomé das Letras. Belo Horizonte: Fundação Estadual do Meio Ambiente. Projeto Associado 4174 Relatório Final, 2009. 143p.

FERNANDES, T. M. G.; GODOY, A. M.; FERNANDES, N. H. Caracterização petrográfica química e tecnológica dos quartzitos do centro produtor de São Tomé das Letras, sudoeste do estado de Minas Gerais. In: Anais do SIMPÓSIO DE ROCHAS ORNAMENTAIS DO NORDESTE, 3, 2002. Recife: Centro de Tecnologia Mineral, 2002. p.3842.

FERRARA, L. D. Olhar periférico: informação, linguagem e percepção ambiental. São Paulo, USP, 1999. 346p.

GOHN, M. G. Educação não-formal, participação da sociedade civil e estruturas colegiadas nas escolas. Ensaio: Avaliação de Políticas Públicas Educacionais, Rio de Janeiro, v.14, n.50, 2006, p.27-38.

HEIMSTRA, N. W., MCFARLING, L. H. Psicologia Ambiental. São Paulo: EPU/EDUSP, 1978. 218p.

IBGE. Instituto Brasileiro de Geografia e Estatística. Disponível em www.ibge.gov.br. Acessado em 28 de outubro de 2011.

IGA. Instituto de Geociências Aplicadas. Disponível em www.iga.br. Acessado em 28 de outubro de 2011.

INMET. Instituto Nacional de Meteorologia. Normais Climatológicas do Brasil 1961-1990. Disponível em www.inmet.gov.br. Acessado em 23 de outubro de 2011.

LOPES, C. M. S. Direito do trabalho da mulher: da proteção à promoção. Cadernos Pagu, 2006. p. 405-430.

MACHADO, L. M. C. P. Qualidade ambiental: indicadores quantitativos e perceptivos. In: RIO, V. D; OLIVEIRA, L. Percepção ambiental: a experiência brasileira. São Paulo: Studio Nobel, 1996. p.97-119.

MARIN, A. A.; OLIVEIRA, H. T.; COMAR, V. A educação ambiental num contexto de complexidade do campo teórico da percepção. Interciência, Caracas, v. 28, n. 10, 2003, p.616-619.

MARQUES-NETO, R. Evolução de caverna em quartzito e processos cársticos em São Tomé das Letras-MG: contribuição ao estudo de sistemas cársticos em rochas silicáticas. Geosul, Florianópolis, v. 23, n. 45, 2008. p.105121.

MERLEAU-PONTY, M. Fenomenologia da Percepção. 4 ed. São Paulo: Editora WMF Martins Fontes. 2011. 662p.

MINAYO, M. C. S.; SANCHES, O. Quantitativo-Qualitativo: Oposição ou Complementaridade? Cadernos de Saúde Pública. Rio de Janeiro, v.9, n.3, 1993. p.239-262.

MORAN, E. F. Adaptabilidade Humana. Uma Introdução à Antropologia Ecológica. 2. ed. São Paulo: Editora da Universidade de São Paulo, Editora SENAC São Paulo, 2010. 512p.

MORIN, E. A cabeça bem feita: repensar a reforma, reformar o pensamento. 5 ed. Rio de Janeiro: Bertrand, Brasil, 2008. 128p.

MORIN, E. O Método I: A natureza da natureza. Portugal: Publicações Europa-América Ltda., 1997. 364p.

MORIN, E. O Método IV: As idéias, a sua natureza, vida, habitat e organização. Portugal: Publicações Europa-América Ltda., 1991. 236p.

MORIN, E. Os sete saberes necessários à educação do futuro. 2. ed, São Paulo : Cortez Brasília, DF , UNESCO, 2000. $118 p$.

OLIVEIRA-FILHO, A. T.; FLUMINHAN-FILHO, M. Ecologia da Vegetação do Parque Florestal Quedas do Rio Bonito. Revista Cerne v. 5, n. 2, 1999. p.51-64.

PERUZZO, C. M. K. Comunicação comunitária e educação para a cidadania. PCLA, v.4, n.1. Universidade Metodista de São Paulo, Brasil. 2002. Disponível em www2.metodista.br/unesco/PCLA/revista13/artigos\%2013-3.htm. Acessado em 06 de dezembro de 2011. 
PNES. Programa Nacional de Eliminação da Silicose. Proposta Preliminar. Resultado da Oficina de Trabalho realizada na sede da Organização Internacional do Trabalho em Brasília, 2001. Disponível em www.pgt.mpt.gov.br/publicacoes/seguranca/pnes.pdf. Acessado em Acessado em 06 de dezembro de 2011.

PREFEITURA MUNICIPAL DE SÃO TOMÉ DAS LETRAS. Disponível em www.saotomedasletras.mg.gov.br. Acessado em 06 de dezembro de 2011.

REZENDE, M. A. P.; PEREIRA, A. F.; CASTRIOTA, L. B.; COSTA, S. A. P.; FREITAS, V. L. O.; LOPES, R. M. F.; D’AURIA, C. A. Pedra são tomé: valoração regional por meio da revitalização da paisagem e da identidade cultural. Relatório final de pesquisa, Escola de Arquitetura da Universidade Federal de Minas Gerais. Belo Horizonte: FAPEMIG. 2009. 402p.

ROSUMEK. F. B. Conservar por quê? As motivações e objetivos da ideologia ambientalista. Dissertação de Mestrado, Departamento de Biologia Geral, UFMG, 2009. 98p.

SAUVÉ, L. Environmental Education and Sustainable Development: A Further Appraisal. Canadian Journal of Environmental Education, 1, 1996. p.7-34.

SAUVÉ, L.; BARBA, A. T.; SATO, M.; CASTILLO, E. La educación ambiental: una relación constructiva entre la escuela y la comunidad. EDAMAZ e UQÀM, Montreal, Canadá, 2000. 167p.

SEMAD. Secretaria de Estado de Meio Ambiente e Desenvolvimento Sustentável. Disponível em www.semad.mg.gov.br/noticias/1/1441-operacao-fiscalizou-68-empreendimentos-minerarios-em-sao-thome-dasletras. Acessado em 01 de fevereiro de 2012.

SILVEIRA, E. J, S. Turismo religioso popular? Entre a ambigüidade conceitual e as oportunidades de mercado. Revista de Antropología Experimental. n. 4, 2004. 16p.

TRAVASSOS, L. E. P.; VARELA, I. D.; GUIMARAES, R. L. Áreas cársticas, cavernas e a Estrada Real. Campinas, SeTur/SBE. Pesquisas em Turismo e Paisagens Cársticas, v.1, n.2, 2008. p.107-120.

TUAN, Y. F. Espaço e lugar, a perspectiva da experiência. São Paulo: Ed. DIFEL, 1983. 250p.

VIANA, M. B.; BURSZTYN, M. A. A. Regularização ambiental de minerações em Minas Gerais. Revista Escola de Minas, v.63, n.2, 2010. p.363-369. 


\section{LOPES et al., v(11), no 11, p. 2326 - 2359, JAN-ABR 2013.}

ANEXO 1. Roteiro para entrevistas dirigidas às lideranças de São Tomé das Letras, MG.

A Universidade Federal de Minas Gerais (UFMG) e a Fundação Centro Tecnológico de Mınas Geraıs (CETEC) estão realizando uma pesquisa no município de São Tomé das Letras. Seu objetivo é contribuir futuramente para a educação ambiental e patrimonial da comunidade.

As informações obtidas serão utilizadas unicamente para o estudo. Todos os dados fornecidos são confidenciais, garantimos o sigilo pessoal.

\section{PERFIL SOCIAL}

1- $\quad$ Sexo (colocar sem perguntar):

2- Idade:

3- Estado civil:

4- Número de filhos:

5- Escolaridade (colocar o curso, pós-graduação...):

6- Profissão atual:

Tempo de profissão:

7- Profissão anterior:

Tempo de profissão:

No caso de professor, perguntar disciplina e série:

8- Religião:

9- Local de residência (bairro, zona rural ou urbana...):

10- Tempo de residência em São Tomé:

\section{PERGUNTAS}

1. Cite três coisas boas da cidade e seus arredores. Por quê?

2. Cite três coisas que você mudaria na cidade e seus arredores. Por quê?

3. O que é meio ambiente para você?

4. Se você fosse escolher um símbolo para a cidade de São Tomé, o que seria? Por quê?

5. Você se informa sobre o meio-ambiente? Como?

6. Em sua opinião, qual a melhor idade para se começar a aprender sobre o meio ambiente? Por quê?

7. No seu dia a dia, você acha que causa algum prejuízo ao meio ambiente? Por quê?

8. Você acha que é importante preservar a natureza? Por quê?

9. De quem você acha que é a responsabilidade de cuidar do meio ambiente? Por quê?

10. O que você pensa sobre a mineração de São Tomé das Letras?

11. E sobre o turismo em São Tomé das Letras? 